\title{
SOME DIGENETIC TREMATODES IN FISHES FROM THE BAY OF BISCAY AND NEARBY WATERS
}

\author{
By RODNEY A. BRAY
}

CONTENTS

\begin{tabular}{|c|c|c|c|c|c|c|c|c|c|}
\hline SyNOPSIS & . & . & . & . & . & . & . & . & . \\
\hline INTRODUCTION & . & . & . & . & . & . & . & . & . \\
\hline HOST - PARASITE LIST & . & . & . & . & . & . & . & . & . \\
\hline SySTEMATIC SECTION & . & . & . & . & . & . & . & . & . \\
\hline Family BucEPHALIDA & & . & . & . & . & . & . & . & . \\
\hline Family OPECOELIDAE & & . & . & . & . & . & . & . & . \\
\hline Family LEPOCREADIII & $\mathrm{DAE}$ & . & . & . & . & . & . & . & . \\
\hline Family AzYGIIDAE & . & . & . & . & . & . & . & . & . \\
\hline Family ZoOgONIDAE & . & . & . & . & . & . & . & . & . \\
\hline Family FeLLODISTOM & IDAE & . & . & . & . & . & . & . & . \\
\hline Family Hemiuridae & . & . & . & . & . & . & . & . & . \\
\hline ACKNOWLEDGMENTS . & . & . & . & . & . & . & . & . & . \\
\hline REFERENCES . & . & . & . & . & . & . & . & . & . \\
\hline
\end{tabular}

SYNOPSIS

Sixteen species of digenetic trematodes are recorded from seventeen species of fishes caught in the Bay of Biscay and in waters off the north-west coast of Spain and the Atlantic coast of Morocco.

The following two species are described as new : Bathycreadium biscayense and Steringophorus blackeri. Seven of the remaining species are described, these are Dolichoenterum longissimum Ozaki, Prosorhynchus crucibulum (Rud.), Lepidapedon rachion (Cobbold), L. elongatum (Lebour), Steganoderma abyssorum (Odhner), Neosteganoderma glandulosum Byrd and (?) Steringotrema divergens (Rud.). The following new combinations are made : Bathycreadium [Nicolla] elongatum (Maillard) and Neosteganoderma [Proctophantastes] polymixiae (Yamaguti).

\section{INTRODUCTION}

THE author was given the opportunity in I97I to obtain parasitic worms from marine fishes, whilst accompanying a cruise of the Ministry of Agriculture, Fisheries and Food Research Vessel 'Cirolana', the primary purpose of which was to collect blood from hake for electrophoretic and chromosome studies. The collecting was carried out between the Ist and the I4th of January and was conducted primarily in the Bay of Biscay, but also in other areas, including the waters off the western coasts of Spain and Morocco. The locations of the stations mentioned in this report are shown on Fig. I and further details are given in Table I.

The fish were caught by stern trawl and the alimentary tract removed from them. The stomach and intestine were separated before being opened up with scissors, and then the contents were shaken into a tube of sea-water. These tubes were kept for 


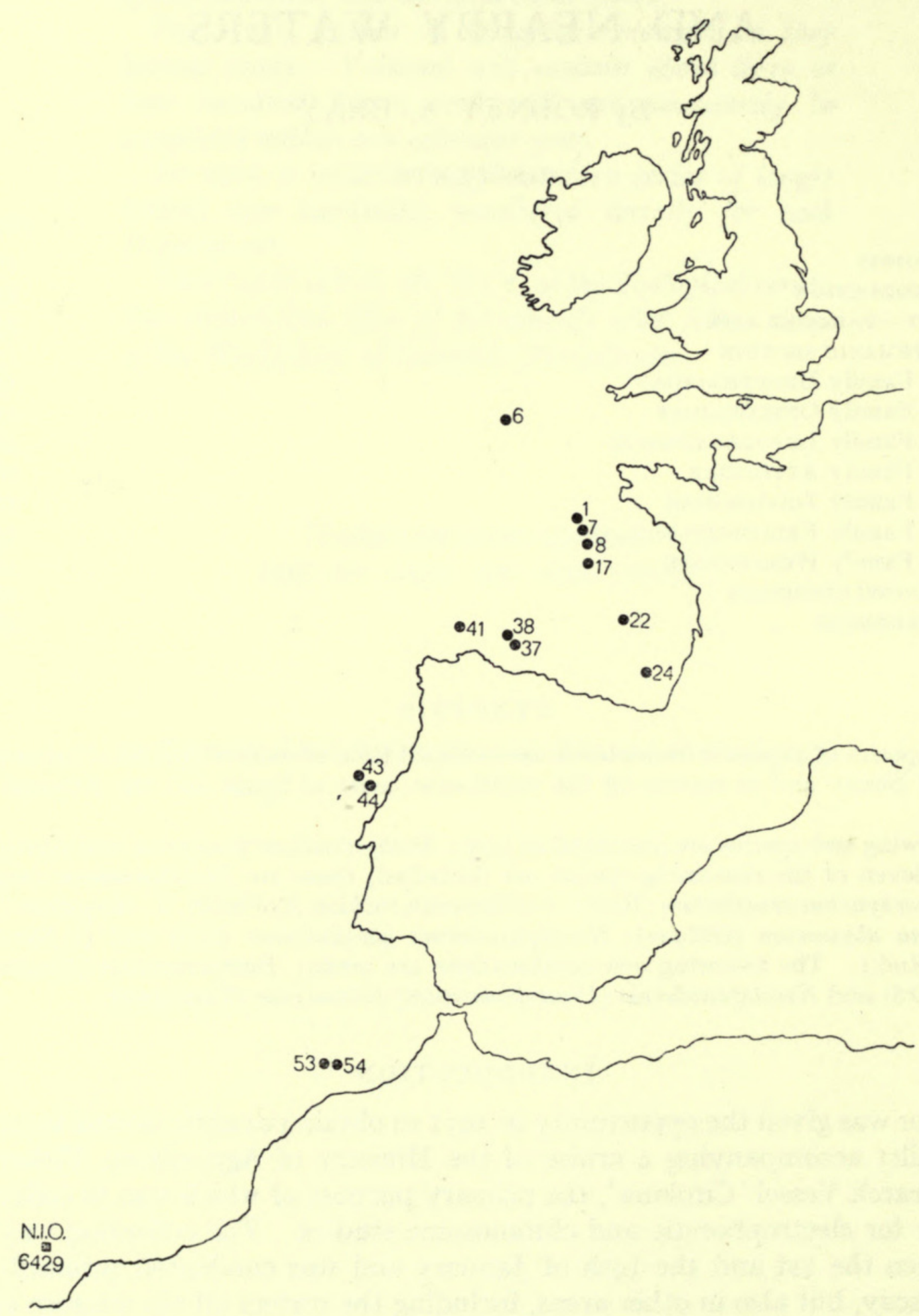

FIG. I. Map showing positions of stations mentioned in this report. 
善自

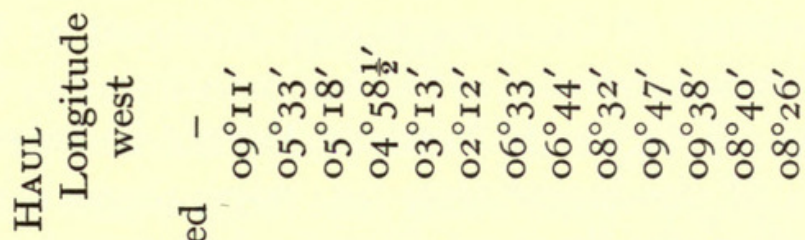

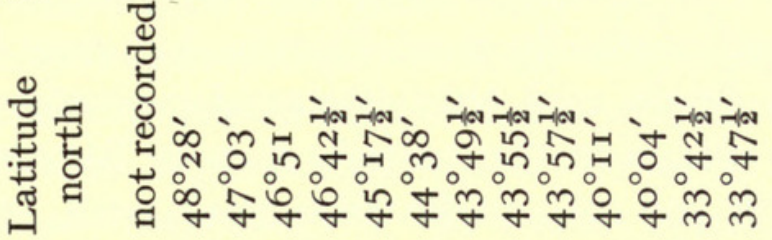

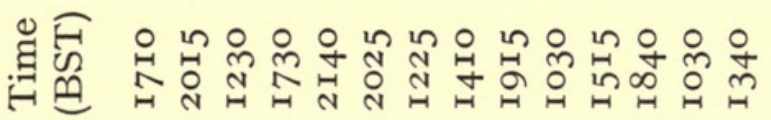

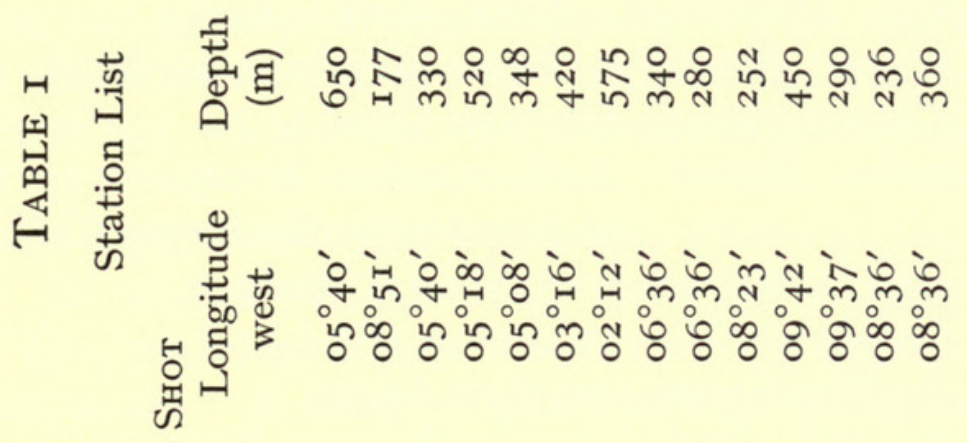

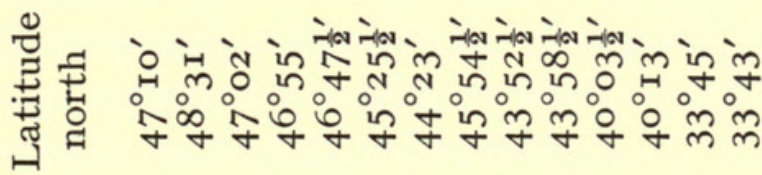

盖盛

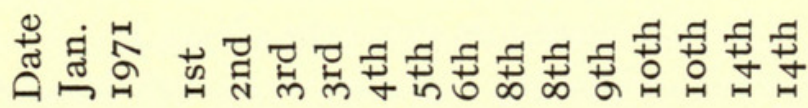

完

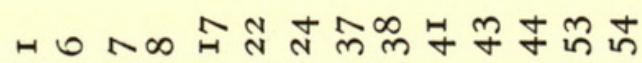


periods of up to six hours in a refrigerator at just above freezing point, before being topped up with a fixative, either 'Dowicil' or Io per cent formalin. A degree of contraction resulted from the use of these fixatives.

The material from the 'Cirolana' cruise was supplemented by two trematodes collected from preserved fish in the collection of the National Institute of Oceanography (now the Institute of Oceanographic Sciences) at Wormley, Surrey.

The parasites of seventeen species of fish are mentioned in this report. The majority of the sixteen species of digenetic trematodes studied are already well known as widespread species. It is interesting to note, however, that Neosteganoderma glandulosum, reported originally from Florida, has now been recovered from off the north-west coast of Spain and that Steganoderma abyssorum, previously reported only from Norway, occurs in the eastern Bay of Biscay. Further evidence of the affinities of species in the area under discussion with Florida on one hand, and the north-eastern North Atlantic on the other, is indicated by the finding of two new species whose closest relatives appear to be species from these two areas.

HOST - PARASITE LIST

Alosa fallax (Lacépède) - Hemiurus appendiculatus (Rud.).

Beryx decadactylus Cuvier - Neosteganoderma glandulosum Byrd.

Capros aper (L.) - (?) Steringotrema divergens (Rud.).

Coelorinchus caelorhinchus (Risso) - Bathycreadium biscayense sp. nov.

Steganoderma abyssorum (Odhner).

Conger conger (L.) - Dolichoenterum longissimum Ozaki.

Prosorhynchus crucibulum (Rud.).

Lecithochirium gravidum Looss.

Dalatias licha (Bonnaterre) - Otodistomum veliporum (Creplin).

Gaidropsarus vulgaris (Cloquet) - Helicometra fasciata (Rud.).

Lepidion eques (Günther) - Bathycreadium biscayense sp. nov.

Lepidapedon elongatum (Lebour).

Steganoderma abyssorum (Odhner).

Lophius piscatorius L. - Bucephalopsis gracilescens (Rud.).

Merluccius merluccius (L.) - Derogenes varicus (Müller).

Micromesistius poutassou (Risso) - Derogenes varicus (Müller).

Molva macrophthalma (Rafinesque-Schmaltze) - Derogenes varicus (Müller).

Phycis blennoides (Brünnich) - Lepidapedon rachion (Cobbold).

Derogenes varicus (Müller).

Scomber scombrus L. - Lecithocladium excisum (Rud.).

Trachyrhynchus trachyrincus (Risso) - Bathycreadium biscayense sp. nov.

Lepidapedon elongatum (Lebour).

Steganoderma abyssorum (Odhner).

Derogenes varicus (Müller).

Xenodermichthys copei (Gill) - Steringophorus blackeri sp. nov.

Xenodermichthys sp. indet. - Steringophorus blackeri sp. nov. 
Family BUGEPHALIDAE Poche, I907

\section{Dolichoenterum longissimum Ozaki, I924}

(Fig. 2)

Host and locality: intestine of Conger conger, Stn. 7 .

Twenty-three specimens were found, and these vary from 3.5 to $6.5 \mathrm{~mm}$ in length. The longer worms are less contracted and have a long narrow neck, and an elongate oval hindbody (Fig. 2a), but in the shorter contracted specimens there is little indication of a neck (Fig. 2b). Whilst, superficially, these two forms may appear distinct an examination of the internal morphology of the worms leaves no doubt that they are specifically identical. The cuticle has, imbedded in it, numerous narrow pointed spines.

The anterior sucker is surmounted by a thick muscular hood, which in an extended condition, bears seven to eight horn-like conical projections on the dorsal and lateral rims (Figs. 2c and d). In an extended condition the sucker is $0.53-0.68 \mathrm{~mm}$ in diameter. When contracted the sucker becomes almost globular, and the projections are less conspicuous, and apparently less numerous in some cases, and point inwards. The sucker in this condition measures $0.32-0.44 \mathrm{~mm}$ in diameter. The aperture of the sucker is subterminal, with a more or less narrow extension down the ventral surface.

The contraction or expansion of the worm also affects the anterior portion of the alimentary canal. In neither whole mounts nor serial sections was evidence of an oral sucker seen. The specimens lacking a neck bear a simple mouth situated closely behind the anterior sucker. A short prepharynx runs posteriorly to the somewhat transversely-oval pharynx measuring $0.3-0.32 \mathrm{~mm} \times 0.2 \mathrm{I} \mathrm{mm}$. From the pharynx the intestine runs anteriorly to a point which may or may not be nearer to the anterior sucker than the pharynx, where it turns conversely to reach the hinder end of the body. In both extended and contracted specimens the intestine follows a transversely undulating course and reaches nearly to the posterior end of the cirrussac. The posterior limit of the intestine is not easy to make out in whole mounts as it is often obscured by the eggs in the uterus.

A sinus occurs at the posterior margin of the worm, normally in the median line, though contraction has, in some cases, displaced the opening to the left of the median line. Into it open the ducts of the male and female systems and of the excretory vesicle. The opening of the sinus does not appear to be surrounded by a sphincter. The elongate cirrus-sac, which, due to contraction, lies at an acute angle to the median line, measures $0.95 \times 0.23-0.28 \mathrm{~mm}$ and possesses a fairly thick muscular wall. It contains an oval seminal vesicle, $0.38-0.43 \mathrm{~mm} \times 0.23-0.25 \mathrm{~mm}$, which occupies the anterior portion of the cirrus-sac. The pars prostatica passes out of the middle region of the seminal vesicle, and runs to near the posterior extremity of the cirrus-sac where it unites with a short muscular cirrus. The testes are transversely elongate, well separated one behind the other, and are situated in the 

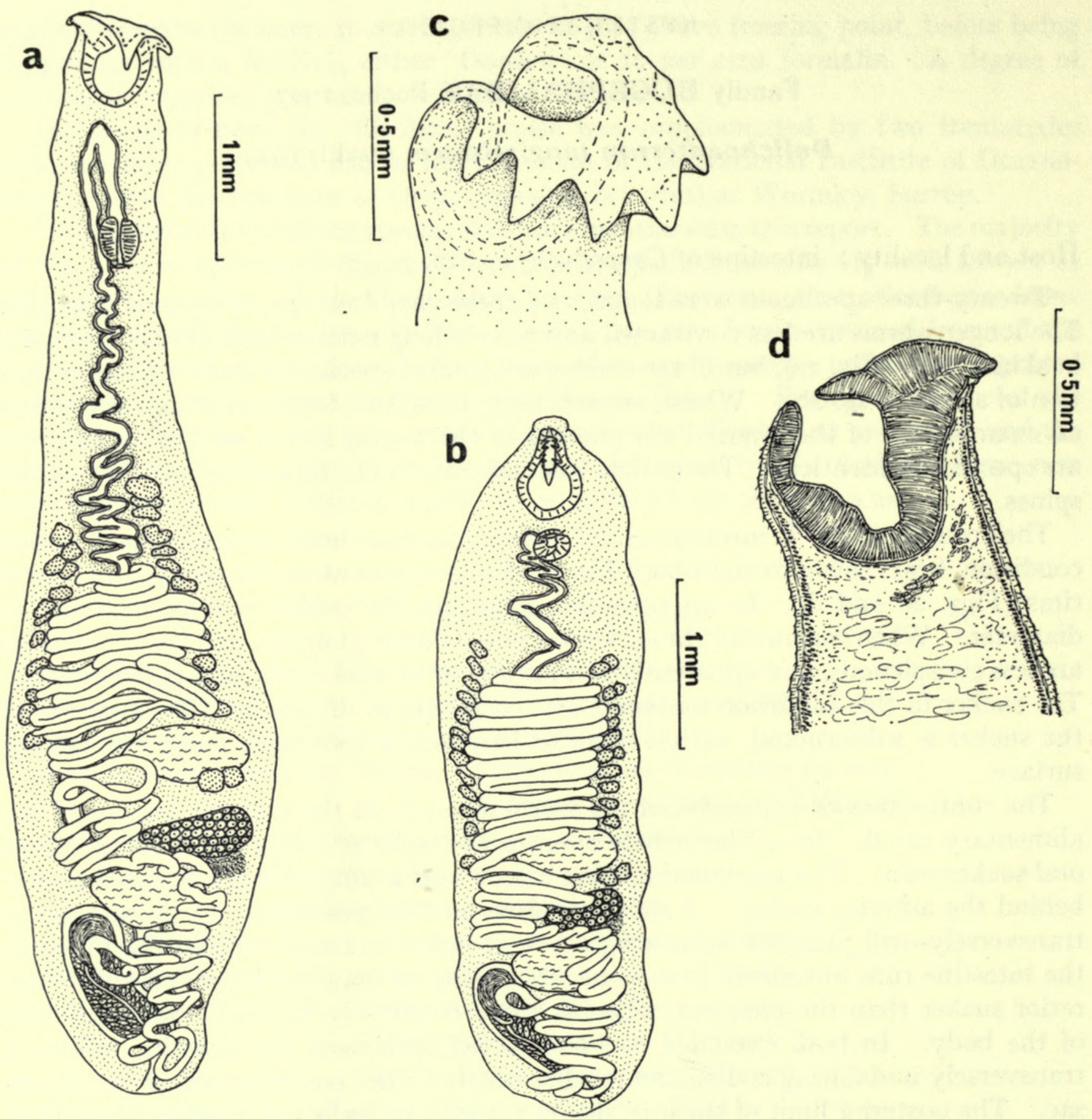

FIG. 2. Dolichoenterum longissimum Ozaki: a) extended specimen (ventral view); b) contracted specimen (ventral view); c) anterior sucker (dorso-lateral view); d) longitudinal section of anterior sucker.

middle region of the hinder half of the body. They are $0.56-0.84 \mathrm{~mm} \times 0.22-0.4 \mathrm{I}$ $\mathrm{mm}$. The ovary is also transversely elongate measuring $0.53-0.82 \mathrm{~mm} \times 0.23-$ $0.34 \mathrm{~mm}$, and lies a little to the left of the median line between the testes. Directly behind it lies a large diffuse Mehlis' gland. Laurer's canal opens dorsally at about the level of the posterior testis. There appears to be no receptaculum seminis, but sperm is accumulated in the initial slings of the uterus, which is long and coiled running to a position some way anterior to the anterior testis before it turns and passes posteriorly, with many tightly-packed transverse slings. It passes into the posterior 
region of the body, where it opens into the base of the genital sinus near the cirrussac, via a short muscular metraterm. There are numerous small eggs, many of which are collapsed, but measuring $2 \mathrm{I}-27 \mu \mathrm{m} \times \mathrm{I} 2-\mathrm{I} 8 \mu \mathrm{m}$ when not collapsed. The vitelline follicles lie in two lateral groups, with about I2-I6 follicles in each group, extending from about the level of the anterior testis to a position anterior to the foremost extent of the uterus. A few follicles also occur scattered between the testes.

The excretory vesicle opens into the genital sinus, and runs forward to a position just posterior to the posterior testis.

Dolichoenterum longissimum was originally described from Conger myriaster in Japanese waters. It has been found a number of times since in the same waters in C. myriaster (Ozaki I928; Yamaguti I938; Machida et al. I970) and in Muraenesox cinereus (Yamaguti I934). Prior to the present record, it has also been found in Conger conger in New Zealand waters (Manter I954) and in two localities off the western coast of Scotland (Williams I960).

Ozaki (I928) and Yamaguti (I934) disagree on the presence of a so-called 'urogenital' pore, that is, the common opening of the genital sinus and the excretory vesicle. Yamaguti states that Ozaki's figure 23 is misleading, and suggests that the 'genital sinus' is no more than a slight depression. Ozaki's figure, however, seems to accurately represent the condition in the present material. It would seem that the depth of the genital sinus is influenced somewhat by the contraction of the body.

Another feature which varies with the condition of the worm is the number and configuration of the projections surmounting the anterior sucker. Such a difference is, according to Tendeiro (I955), a major factor in separating D. manteri Tendeiro, I955 (with only five projections) from $D$. longissimum. Tendeiro found a single specimen of $D$. manteri in $C$. conger from the Algarve coast of Portugal, and considered it distinct for a number of other reasons. The only one of these that appears to be a valid differentiating feature is the length of the intestine, which in $D$. manteri is said to extend only a little behind the middle region of the body. As Tendeiro had but one specimen it may have been that, as is the case in many of my specimens, it was not possible to trace the full extent of the intestine. If this were found to be so, then it seems probable that $D$. manteri should be considered a synonym of $D$. longissimum.

\section{Bucephalopsis gracilescens (Rud., I8I9) Nicoll, I9I4}

Host and locality: intestine of Lophius piscatorius, Stn. 54.

This parasite occurred in great numbers. The shape of these worms varies considerably as indicated by Dawes (I947).

\section{Prosorhynchus crucibulum (Rud., I8I9) Odhner, I905}

(Fig. 3)

Monostoma crucibulum Rud., I8I9.

Distoma crucibulum: Dujardin, I845.

Gasterostomum crucibulum: Gervais and van Beneden, I859. 


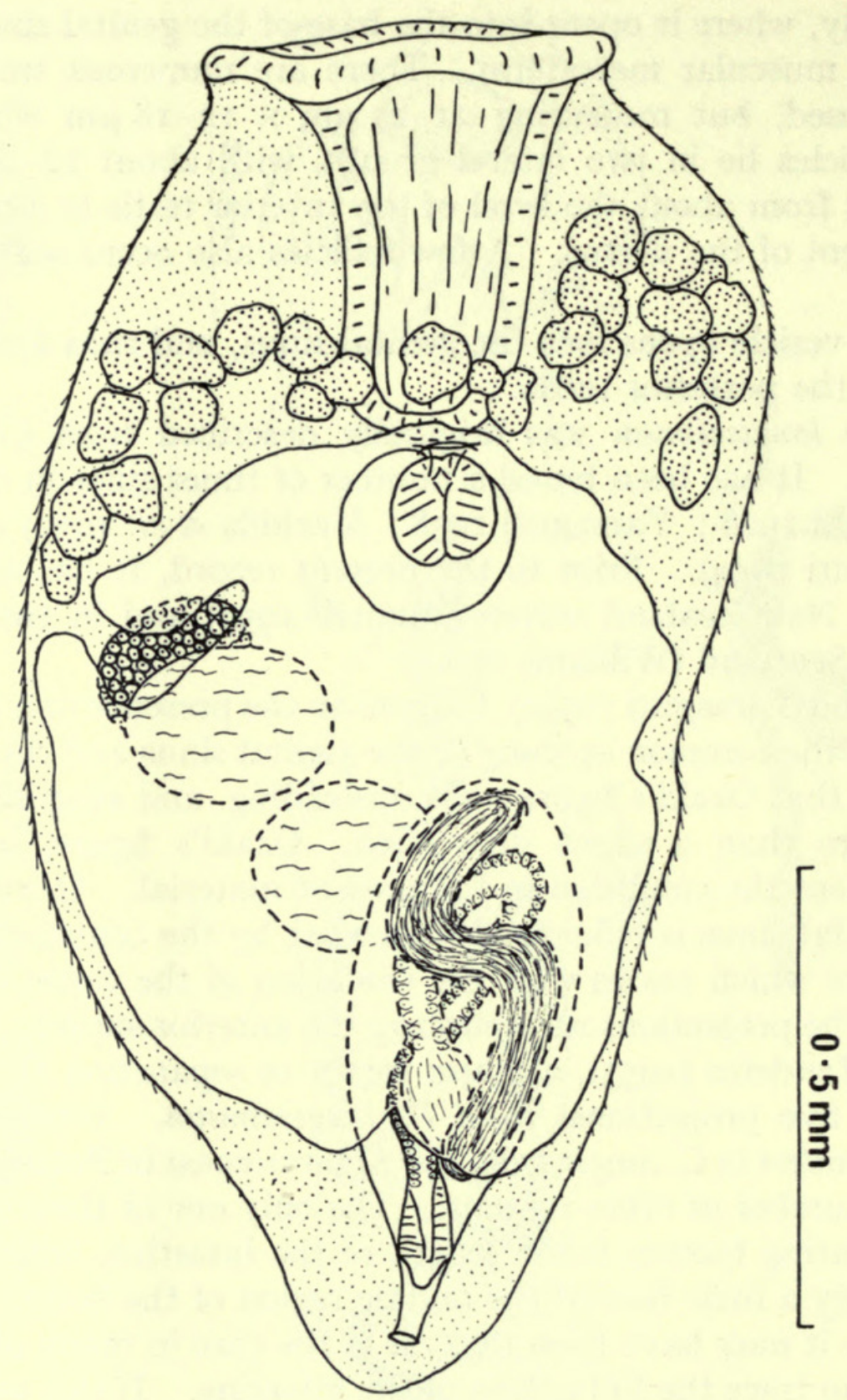

Fig. 3. Prosorhynchus crucibulum (Rud.) : ventral view.

Host and locality: intestine of Conger conger, Stn. 7 .

A single specimen was present, and it was examined as a whole mount and then in serial sections. It is a small worm, truncated anteriorly and pointed posteriorly, $\mathrm{I} .5 \mathrm{~mm}$ in length and $0.87 \mathrm{~mm}$ in maximum width. The cuticle bears numerous scale-like spines. At the anterior end there is a muscular, funnel-shaped rhynchus, $0.48 \mathrm{~mm}$ across at its widest point and extending posteriorly to very near the intestine, that is, about $0.55 \mathrm{~mm}$ from the anterior end of the worm. A slit-like transverse mouth, $52 \mu \mathrm{m}$ across, is situated at about the anterior third of the body length, and near the base of the rhynchus. It leads immediately to a nearly globular pharynx, measuring $0.108 \times 0.115 \mathrm{~mm}$, which in turn leads into a muscular oesophagus 
$0.07 \mathrm{~mm}$ long, thence into the saccular intestine, which lies dorsally to the pharynx and is about $0.2 \mathrm{~mm} \times 0.16 \mathrm{~mm}$.

The excretory pore is terminal posteriorly, and the excretory vesicle reaches to about the level of the anterior end of the cirrus-sac.

The genital sinus opens near to the posterior extremity of the body on the ventral side of the worm. A muscular cirrus-sac, $0.47 \mathrm{~mm}$ long by about $0.22 \mathrm{~mm}$ wide, reaches anteriorly to a position just in front of the anterior margin of the posterior testis. It contains a sigmoid seminal vesicle, which extends from the foremost extremity of the cirrus-sac to a position near to the posterior extremity, where it forms a muscular bulb before passing into an elongate pars prostatica. This latter organ runs nearly to the anterior of the cirrus-sac before passing posteriorly to where it unites with a relatively short muscular cirrus, which opens into the sinus at the base of the genital tongue. There is no indication of an external seminal vesicle. The testes lie one just posterior to the pharynx with the other just behind it. They are oval with smooth margins and measure $0.27 \times 0.19 \mathrm{~mm}$ (anterior testis) and $0.2 \mathrm{I} \times$ $0.2 \mathrm{~mm}$ (posterior testis). The ovary, of similar size and shape to the testes $(0 \cdot 2 \mathrm{~mm}$ dia.), lies just antero-dorsal to the anterior testis. The 'shell'-gland lies immediately posterior to the ovary, and Laurer's canal opens dorsally just posterior to the ovary. The vitellaria consist of about 25 irregular follicles lying more or less in an arc just behind the rhynchus and anterior to the pharynx and uterus. This latter organ is extensive in the region posterior to the pharynx, obscuring parts of the reproductive system in the whole mount. A short, muscular metraterm enters the genital sinus dorsally to the cirrus-sac. The eggs, which are very numerous and mostly collapsed, measure about $24-26 \mu \mathrm{m} \times \mathrm{I} 6-\mathrm{I} 8 \mu \mathrm{m}$.

Prosorhynchus crucibulum is a common parasite of the conger and is morphologically very similar to another parasite of this fish, $P$. aculeatus Odhner, I905, with which it has been synonymized by Dawes (I947). Brinkmann (I957) has given a number of reasons why he considers these species to be distinct, and, having examined a number of specimens assigned to both species in the collections of the British Museum (Natural History), I agree that the features selected by Brinkmann appear to be of value in distinguishing these species. The most noticeable difference is the size and shape of the rhynchus, which in $P$. aculeatus is small and rounded, and in crucibulum is larger and triangular or funnel-shaped. This character appears to be fairly constant, and according to Matthews (I973) the typical shape of the rhynchus in $P$. crucibulum is developed in the metacercaria during its first month in the second intermediate host. As can be seen, the present specimen fits $P$. crucibulum in this, as well as the other less prominent characteristics.

Family OPECOELIDAE Ozaki, I925

Helicometra fasciata (Rud., I8I9) Odhner, I902

Host and locality : intestine of Gaidropsarus vulgaris, Stn. 22.

One specimen was present. 


\title{
Bathycreadium biscayense sp. nov.
}

\author{
(Fig. 4)
}

Hosts and localities : caeca and intestine of Trachyrhynchus trachyrincus (type-host), Stn. 7, Stn. 24 ; caeca and intestine of Coelorinchus caelorhinchus, Stn. I ; intestine of Lepidion eques, Stn. I.

This species occurred commonly in $T$. trachyrincus, in smaller numbers in $C$. caelorhinchus and only one specimen was found in L. eques.

The worm is elongate oval with lateral margins roughly parallel for much of its length, which varies between $0.4 \mathrm{~mm}$ and $\mathrm{I} \cdot 7 \mathrm{~mm}$. The maximum width, which normally occurs at the level of the ventral sucker, is $0.19-0.42 \mathrm{~mm}$. The tegument is not armed, but bears annular wrinkles, probably due to contraction. Circular and subterminal, the oral sucker measures $0.065^{-0} \cdot 14 \mathrm{~mm}$ in diameter and leads, without an apparent prepharynx, into a globular pharynx $0.032-0.066 \mathrm{~mm}$ in diameter. The oesophagus, up to $0.13 \mathrm{~mm}$ in length and lined with a cuticle, bifurcates at about the anterior margin of the ventral sucker. The intestinal caeca reach to near the posterior end of the worm, where they unite to form a cyclocoel. The ventral sucker is situated close behind the oral sucker in the anterior quarter or third of the body. It is often situated on a slight protuberance, and is transversely elongate, its transverse diameter being $0 \cdot 19-0.29 \mathrm{~mm}$, thus giving an oral : ventral sucker ratio of I $: 2 \cdot 2-3 \cdot 5$.

The excretory pore is terminal, and the cylindrical vesicle reaches to the ovary.

The genital pore occurs just to the left of the median line, closely anterior to the ventral sucker. Into it opens a claviform cirrus-sac measuring $0 \cdot 25-0.4 \mathrm{~mm} \times 0.05-$ $0.085 \mathrm{~mm}$, which normally reaches just posteriorly to the ventral sucker, and its posterior extremity lies amongst the uterine coils. It contains a convoluted internal seminal vesicle, a relatively short, oval pars prostatica and a long muscular cirrus. The testes are situated in tandem, close together, in the middle third of the body. They are usually wider than long with entire or slightly indented margins and measure in mature specimens $0.08-0.12 \mathrm{~mm} \times 0.12-0.15 \mathrm{~mm}$ (anterior testis) and 0.09$0 . \mathrm{I} 2 \mathrm{~mm} \times 0 . \mathrm{I} 2-0 . \mathrm{I} 5 \mathrm{~mm}$ (posterior testis).

The ovary is situated anteriorly and adjacent to the foremost testis, usually in the median line, but sometimes moved to one side or the other by the development of the uterus. It is normally wider than long, oval, with smooth margins and measures $0.025^{-0.065} \times 0.083^{-0.1} \mathrm{~mm}$. There appears to be a seminal receptacle lying dorsally to the ovary, but, despite several attempts, it has not been possible to obtain satisfactory serial sections of the female complex, so whether this is a true seminal receptacle or part of the uterus has not been determined, nor has the course of Laurer's canal, if present. The vitellaria consist of numerous oval follicles in lateral fields reaching from about the posterior border of the ventral sucker to near the posterior end of the worm. Behind the posterior testis the fields meet in the ventral plane, and come close together in the dorsal, being separated only by the excretory vesicle. Between the testes, and between the anterior testis and the ovary the follicles may extend towards the median line, but do not reach it. The vitelline fields are sometimes interrupted opposite the ovary and the testes. The 


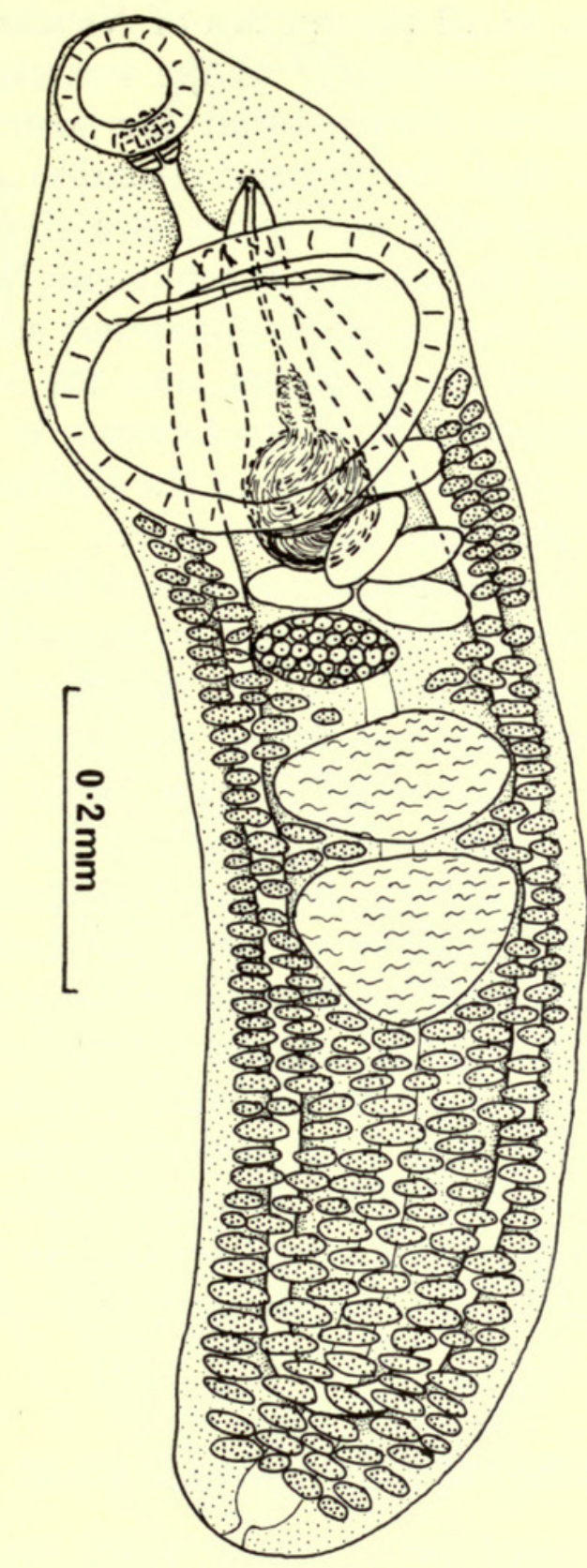

FIG. 4. Bathycreadium biscayense sp. nov. : specimen from Trachyrhynchus trachyrincus (ventral view).

uterus runs from the ovary to the posterior margin of the ventral sucker, and contains a few (up to about Io) large eggs. These measure 80-92 $\mu \mathrm{m} \times 43-52 \mu \mathrm{m}$.

Material. British Museum (Nat. Hist.) Reg. no. I973.4.9.I-20 (syntypes).

Bathycreadium Kabata, I96I, has been reduced to synonymy with Nicolla Wisniewski, I933, by Slusarski (I97I). Kabata did not compare the two genera so it was left to Pritchard (I966) to list the differences between them. Slusarski dismisses Pritchard's diagnostic characters by saying that they are too variable in Nicolla, and he is probably correct in this assumption in respect of most of these characters. It does seem, however, that at least one character mentioned by Pritchard may be used in separating these two genera, along with another feature she did not mention. 
As she noted, it appears that in all the species of Nicolla (with one exception, i.e. $N$. elongata) the vitellaria reach anteriorly to the ventral sucker, whilst in Bathycreadium they do not reach further forward than the posterior margin of the ventral sucker. It is also apparent that the normal situation of the posterior testis in Nicolla is close to, or contiguous with, the cyclocoel with few or no vitelline follicles between the posterior testis and the intestinal arch (again N. elongata is an exception). In Bathycreadium there is at least a testis diameter, usually considerably more, between the posterior testis and the cyclocoel, and the bulk of the vitellaria is in this region. From its differentiating characteristics it is evident that Nicolla elongata Maillard, I970, from Onos tricirratus in the Gulf of Lion should be assigned to Bathycreadium elongatum (Maillard, I970) n. comb.

It may also be mentioned here that the concept of Bathycreadium as given above is close to that of Coitocaecum Nicoll, I9I5, as represented by Yamaguti (I97I). He seems to be in error, however, in stating that the cirrus-sac is 'retort-shaped containing elongate saccular or tubular seminal vesicle, prostatic complex and ejaculatory duct' in Coitocaecum. The type-species of this latter genus, C. gymnophallum Nicoll, I9I5, has, according to the original author, 'no true cirrus-pouch', while Crowcroft (I95I) who re-examined Nicoll's material states that there is 'a small membranous cirrus-sac enclosing a short, terminal portion of the male duct'.

$B$. biscayense differs from the other two species in the genus, $B$. flexicollis Kabata, I96I, and B. elongatum (Maillard, I970), in the anterior extent of the vitellaria, in the proximity of the testes and the ovary and in the sucker-ratio. It also appears that it normally contains fewer eggs than the other species. The egg-size of $B$. biscayense differs greatly from that of $B$. elongatum, but is similar to that of $B$. flexicollis as corrected by Pritchard (I966) and verified by the author from paratype specimens in the collections of the British Museum (Natural History).

\section{Family LEPOGREADIIDAE Nicoll, I935}

Lepidapedon rachion (Cobbold, I858) Stafford, I904

(Fig. 5)

Distomum rachion Cobbold, 1858 .

Lepodora rachiaea: Odhner, I905.

Host and locality: intestine of Phycis blennoides, Stn. I7.

Nine contracted specimens were present. They are small worms $0 \cdot 66-\mathrm{I} \mathrm{mm}$ long and $0.27-0.44 \mathrm{~mm}$ wide, being widest behind the ventral sucker, and tapering towards the anterior end. The cuticle bears rows of closely-set narrow pointed spines. The oral sucker is subterminal, measuring 0.097-0.115 $\mathrm{mm}$ in diameter, and leads into a prepharynx which, when apparent, varies in length up to $44 \mu \mathrm{m}$ and is usually, but not invariably, longer than the oesophagus, which may reach a length of $28 \mu \mathrm{m}$. The pharynx is large and pyriform 0.09-0.13 $\mathrm{mm} \times 0.066-0.106 \mathrm{~mm}$. The intestinal bifurcation occurs close to the ventral sucker, and the caeca, which reach to the posterior end of the body, are wide. The rounded ventral sucker lies in the anterior 


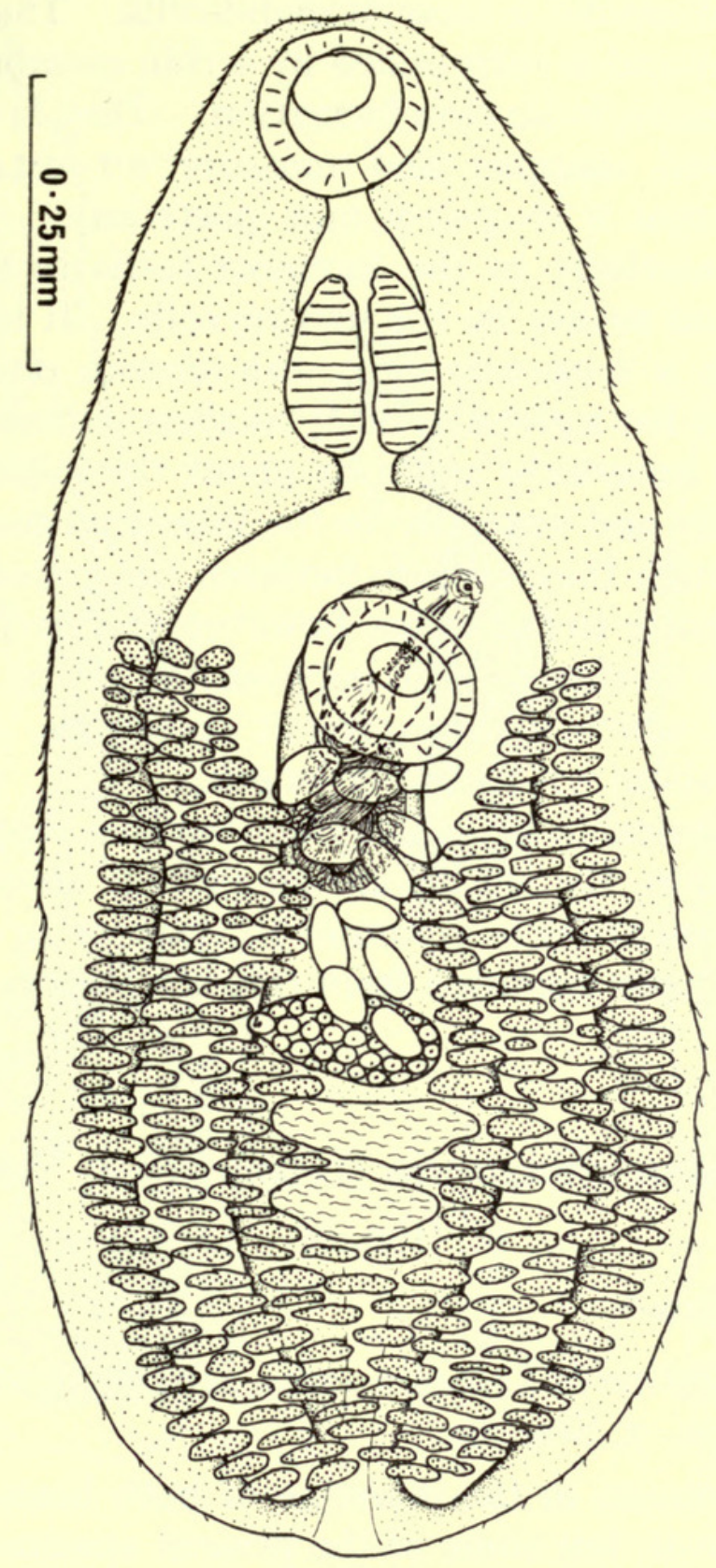

FIG. 5. Lepidapedon rachion (Cobbold) : ventral view.

half of the worm, and measures $0.08-0.12 \mathrm{~mm}$ in diameter, giving an oral : ventral sucker ratio of $I: 0 \cdot 75^{-I} \cdot 08$. Only in the largest specimen was the ventral sucker slightly larger than the oral, whilst in the other specimens the oral sucker was distinctly larger than the ventral.

The excretory pore is terminal and leads into a simple elongate excretory vesicle, which has been traced as far forward as the posterior testis.

The genital pore occurs closely anterior to the ventral sucker and to the left of the median line ; in fact, it lies ventrally to the left caecum. The muscular cirrus-sac reaches to near the posterior margin of the ventral sucker, measures about $0.09 \mathrm{~mm}$ in length and contains a coiled, tubular, seminal vesicle and a pars prostatica, which is slightly longer than the short muscular cirrus. The external seminal vesicle is 
also tubular and is coiled amidst a mass of gland-cells. This mass of cells extends behind the ventral sucker and is surrounded by a thin membrane. In the posterior third of the body lie the testes, in tandem formation. They are transversely elongate, have smooth or indented margins and measure $0.1-0.14 \mathrm{~mm} \times 0.03-0.05 \mathrm{~mm}$ (anterior) and $0.08-0.14 \mathrm{~mm} \times 0.04-0.06 \mathrm{~mm}$ (posterior).

The ovary lies just anteriorly to the foremost testis in the median line and is separated from the ventral sucker by the uterine coils. It is transversely elongate, measuring $0.08-0.13 \mathrm{~mm} \times 0.04-0.07 \mathrm{~mm}$, with smooth or slightly indented margins. Dorsal to the ovary lies a globular receptaculum seminis. The vitelline glands are numerous and reach anteriorly as far as about the middle level of the ventral sucker. They lie laterally and ventrally to the intestinal caeca and reach inwardly to the gonads, and although they intrude between the gonads they do not meet in the median line. Posteriorly to the testes, however, the vitelline fields are confluent in the median line. The uterine coils lie between the ovary and the ventral sucker and contain eggs, all of which, in the present specimens, are collapsed. In this condition they measure about $57-60 \mu \mathrm{m}$ in length.

These worms are recognizable as Lepidapedon rachion despite the fact that, presumably due to contraction, the worms are on average shorter than is normal for this species. This parasite is fairly common in Gadidae in the northern Atlantic, but has not, apparently, been recorded from this host before.

\section{Lepidapedon elongatum (Lebour, I908) Nicoll, I9IO}

(Fig. 6)

Lepodova elongatum Lebour, 1908.

Hosts and localities : intestine of Lepidion eques, Stn. I ; intestine of Trachyrhynchus trachyrincus, Stn. I, Stn. 7, Stn. 24.

These worms were common in the intestine of both hosts. Their normal shape appears to be elongate oval, but some of the present specimens are contracted to a more pyriform shape, whilst some, taken from a frozen specimen of $L$. eques, are very elongate in the forebody. The length of the worm varies between $0.73 \mathrm{~mm}$ and 2.I $\mathrm{mm}$, and the width between $0.17 \mathrm{~mm}$ and $0.42 \mathrm{~mm}$. The cuticle bears rows of narrow pointed spines. Rounded and subterminal, the oral sucker measures $0.09-0.17 \mathrm{~mm}$ in diameter. The ventral sucker, which is situated in the middle third of the body, is also rounded and measures $0.06-0.13 \mathrm{~mm}$ in diameter. The oral : ventral sucker ratio is $I: 0 \cdot 55^{-I}$. The prepharynx in grossly contracted specimens is not apparent, but in less contracted specimens it varies greatly in length, measuring up to $0.6 \mathrm{~mm}$ in one specimen from a frozen $L$. eques. Normally, the variation appears to be between about $0.0 \mathrm{Im}$ and $0.1 \mathrm{~mm}$. The pharynx is longer than wide, measuring $0 \cdot 06-0.14 \mathrm{~mm} \times 0.04-0.12 \mathrm{~mm}$ and has a tendency to be of a similar size to or somewhat larger than the ventral sucker. It leads into the oesophagus which, like the prepharynx, varies considerably in length, and is usually shorter than the prepharynx, being $0-0.06 \mathrm{~mm}$ in length. It bifurcates about midway 

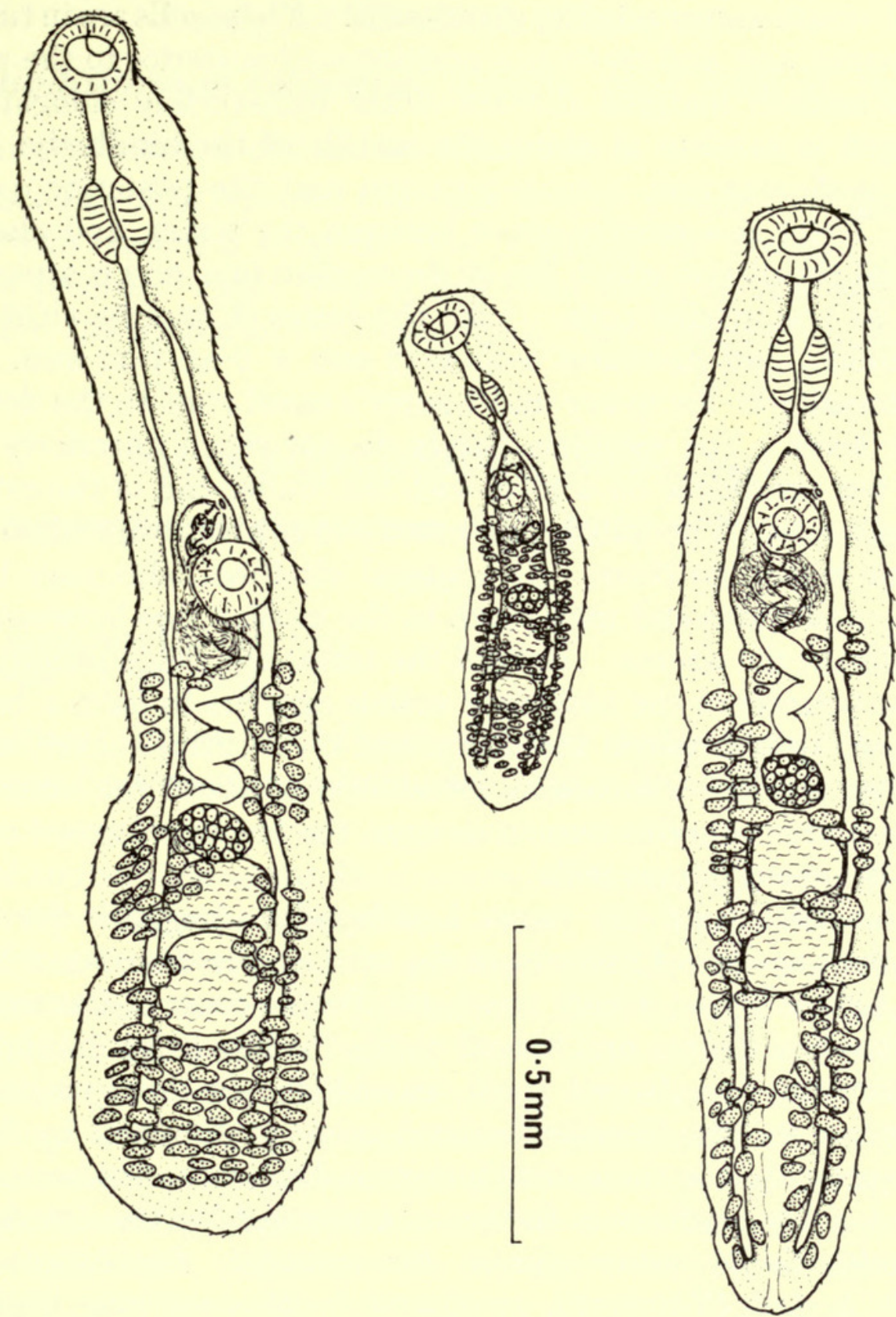

FIG. 6. Lepidapedon elongatum (Lebour) : three specimens from Trachyrhynchus trachyrincus (ventral view).

between the suckers or nearer to the ventral sucker. The caeca, lined with a deeply staining epithelium, reach to near the posterior end of the body.

The excretory pore is terminal and leads into a simple tubular vesicle which has been traced anteriorly to the level of the hinder margin of the hinder testis.

The genital pore is situated to the left of the median line close to the anterior margin of the ventral sucker or more further forward. The strongly muscular, oval cirrus-sac measures about $0.07-0.14 \mathrm{~mm} \times 0.04-0.09 \mathrm{~mm}$, but is not easy to measure satisfactorily due to the angle at which it lies to the body surface. It contains a coiled tubular seminal vesicle, a distinctly widened pars prostatica and a muscular cirrus. The internal seminal vesicle leads, via a narrow canal, into a convoluted 
external seminal vesicle surrounded by gland-cells. These cells are in turn surrounded by a very thin membrane, and reach to a position well posterior to the ventral sucker. The testes have smooth margins and are either transversely elongate or rounded. They are arranged in tandem at about the middle of the hindbody. The anterior testis measures $0.08-0.22 \mathrm{~mm} \times 0.04-0.13 \mathrm{~mm}$ and the posterior $0.09-0.2 \mathrm{~mm} \times$ $0.04-0.16 \mathrm{~mm}$. There is a narrow space between the testes, and also between the anterior testis and the ovary, which lies in the median line, and is separated from the ventral sucker by the uterine coils. Like the testes it may be either transversely elongate or rounded, and measures $0.06-0.17 \mathrm{~mm} \times 0.04-0.1 \mathrm{Imm}$. The seminal receptacle lies dorsally to the ovary and Laurer's canal runs to the dorsal surface at about the same level. The vitelline glands do not reach anteriorly as far as the ventral sucker, but terminate on a level with the hinder end of the external seminal vesicle, or thereabouts. The follicles lie mostly in a plane ventral to the intestinal caeca, with some lateral to them. The lateral vitelline fields may be interrupted beside the ovary and testes and may reach to the median line between these organs, and also ventrally to the uterus. Behind the testes the fields usually merge in the median line, but sometimes the excretory vesicle appears to form a barrier between them. The uterus runs between the ovary and the ventral sucker, and opens into the genital atrium through a muscular metraterm of about the same length as the cirrus-sac. The uterus contains numerous eggs, the few uncollapsed ones measuring $58-65 \mu \mathrm{m}$ long by about $30 \mu \mathrm{m}$ wide.

Several authors have used the name Lepidapedon elongatum for specimens described from various species of fishes from the west and east coasts of North America (Manter I926 ; Linton I940 ; Ching I96I), the Pacific coast of Panama (Caballero y C. et al. I955), Bombay (Gupta and Sehgal I97I), the Black Sea (Skrjabin and Koval I960) and the Barents Sea (Dogiel I936), in addition to those originally described from Gadus morhua on the Northumberland coast of England by Lebour (I908). The variation represented in these descriptions indicates that more than one species may be involved. The position is further complicated by the descriptions of very similar trematodes under other names, for example, Lepidapedon coelorhynchi Yamaguti, I938, L. gadi (Yamaguti, I934) and L. microcotyleum Dollfus, I953. It seems that the latter two species may be distinguished from Lebour's form by eggsize, although their egg-size overlaps some of the later descriptions of 'L. elongatum'. L. coelorhynchi was considered a synonym of L. elongatum by Hanson (I950) and this has been accepted by most subsequent authors.

The specimens described above differ from Lebour's description in that most of them have a ventral sucker distinctly smaller than the oral. She gives measurements of only one specimen, the ventral sucker being $0.12 \mathrm{~mm}$ across and the oral, $0 \cdot I \mathrm{~mm}$ across. It should be noted, however, that in her figure the ventral sucker appears to be slightly smaller than the oral. The distribution of the vitellaria between the ovary and the ventral sucker is rather variable and probably not a good feature to use for differentiating species in this group, as was suggested by Polyanski (I955). Figure 6 illustrates variation in three specimens from the intestine of the same specimen of $T$. trachyrincus, but at the same time they also show a certain constancy of morphological features. 
Family AZYGIIDAE Odhner, IgII

Otodistomum veliporum (Creplin, I837) Stafford, I904

Host and locality: intestine of Dalatias licha, Stn. I.

This trematode has been reported from this host by a number of authors, including Dollfus (I937) who records it from the Bay of Biscay, off Biarritz, and also gives a list of previous records. Since then it has been found in this host in Norwegian waters by Bråten (I964) and in the Cook Strait, New Zealand, by Manter (I954).

\section{Family ZOOGONIDAE Odhner, IgII}

\section{Steganoderma abyssorum (Odhner, I9II) Manter, I947}

(Fig. 7)

Proctophantastes abyssorum Odhner, I9II.

Devetrema abyssorum: Price, 1934.

Hosts and localities : intestine of Trachyrhynchus trachyrincus, Stn. I, Stn. 7, Stn. 24 ; intestine of Coelorinchus caelorhinchus, Stn. I, Stn. 37 ; intestine of Lepidion eques, Stn. I.

The degree of contraction of the fixed worms varies considerably so that the shape varies from a very elongate pyriform to a short, broadly pyriform. The length is between $0.62 \mathrm{~mm}$ and $\mathrm{r} .66 \mathrm{~mm}$ and the greatest width is $0.28-0.63 \mathrm{~mm}$, which occurs invariably at the region of the ventral sucker. The rounded oral sucker is subterminal, $0 \cdot 18-0.32 \mathrm{~mm}$ in diameter, whilst the ventral sucker is considerably larger, situated somewhat posteriorly to the middle of the worm, and is wider than long, being $0 \cdot 25-0.6 \mathrm{~mm}$ across by $0 \cdot 18-0.44 \mathrm{~mm}$. Transversely across the inside of the ventral sucker runs a low muscular ridge. The oral : ventral sucker width ratio is $I$ : $I \cdot 08-2 \cdot I$ and the sucker length ratio is $I: 0 \cdot 9-I \cdot 6$. Only in extended specimens is a prepharynx to be seen, and it reaches to no greater length than $0.04 \mathrm{~mm}$. The small globular pharynx has a diameter of $0.03-0.08 \mathrm{~mm}$ and from it leads an oesophagus which varies greatly in length between $0 \cdot 08-0 \cdot 22 \mathrm{~mm}$. In grossly contracted specimens it has not been observed. It bifurcates about halfway between the suckers and the caeca are fairly short, terminating dorsally to the testes or vitellaria.

The excretory pore is terminal and leads into a vesicle which reaches forward, dorsally to the uterus, for an undetermined distance and as far as can be seen is a simple tube.

Approximately on a level with the intestinal bifurcation, in a submarginal position, lies the genital pore. The cirrus-sac reaches past the anterior margin of the ventral sucker, and in contracted specimens nearly reaches to the transverse ridge, measuring $0.2-0.37 \mathrm{~mm} \times 0.06-0.09 \mathrm{~mm}$. It contains a coiled seminal vesicle, the coils of which are often tightly packed, a well-developed pars prostatica invested with a mass of gland cells and a cirrus, of about one-third the length of the cirrus-sac. The proximal half of the cirrus appears to be lined with a cuticle which may be thrown in wrinkles. The two oval or elongate oval testes are always partly obscured by the 

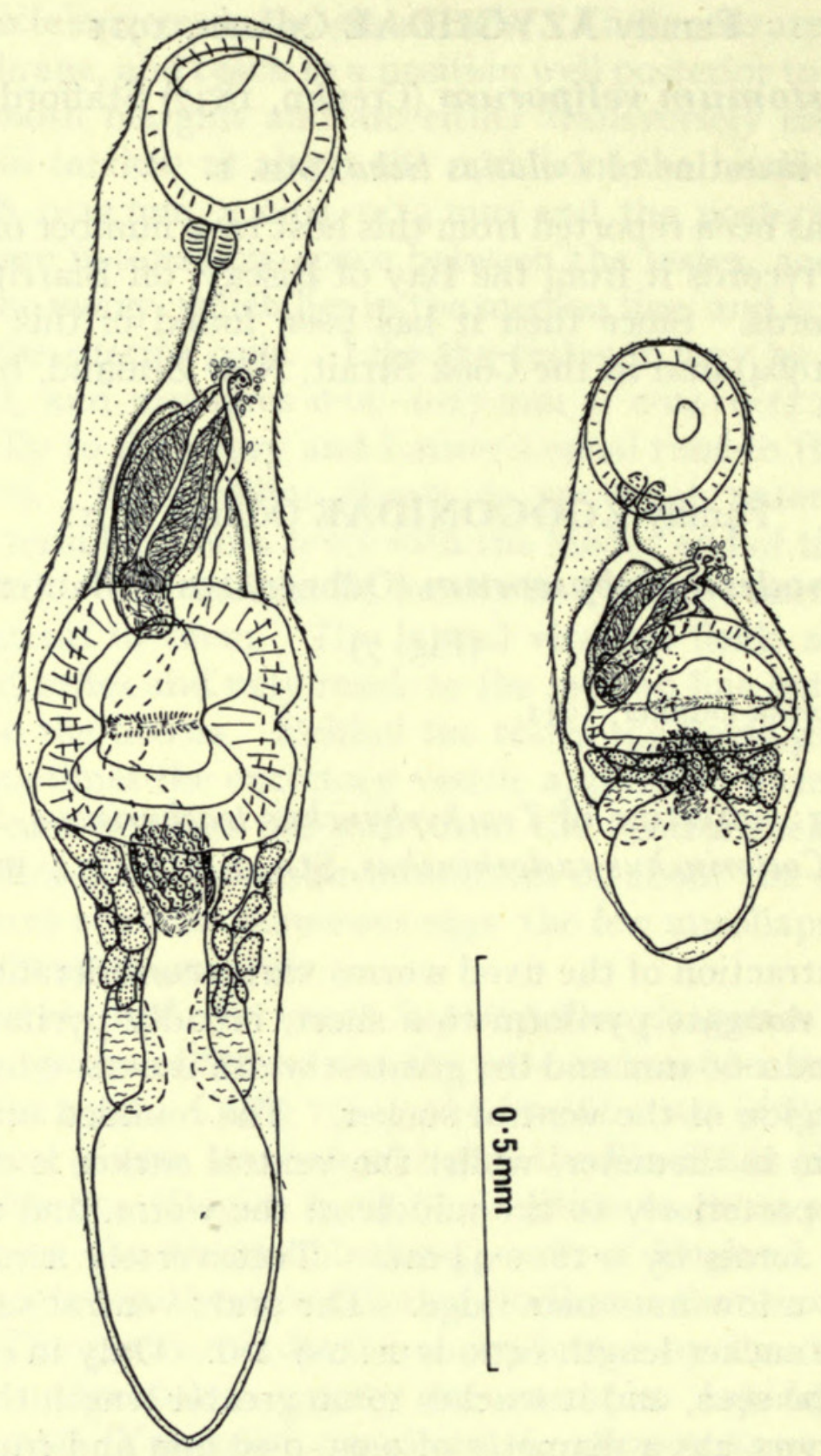

FIG. 7. Steganoderma abyssorum (Odhner) : two specimens from Trachyrhynchus trachyrincus (ventral view).

eggs or the vitelline glands and lie symmetrically one on each side of the body, separated from the posterior border of the ventral sucker by some of the vitellaria. They measure about $0.16-0.22 \mathrm{~mm} \times 0.13-0.2 \mathrm{~mm}$.

The rounded ovary is smaller than the testes, being about $0.15 \mathrm{~mm}$ in diameter. It is situated more or less on the posterior border of the ventral sucker, but sometimes entirely posterior or anterior to it. Posteriorly and dorsally to the ovary lies the rounded or oval seminal receptacle, which is rather smaller than the ovary. Immediately posterior to the ventral sucker, in two symmetrical lateral groups, are the vitellaria, which lie somewhat ventrally to the testes, and overlap them in varying degrees. There are between five and ten follicles in each group. The uterus fills 
most of the area posterior to the ventral sucker, and therefore in the majority of specimens the details of the reproductive organs are obscured. It contains numerous operculate eggs measuring $34-4 \mathrm{I} \mu \mathrm{m}$ long by $\mathrm{I} 6-2 \mathrm{I} \mu \mathrm{m}$. The metraterm is long, muscular and helical. It enters a small, muscular genital atrium, which is surrounded by a scattering of glandular cells.

This species was originally described as the type-species of the genus Proctophantastes Odhner, I9II, from Macrurus (Coryphaenoides) rupestris and Gadus aeglefinus from Norway. Price (I934) considered Proctophantastes to be a synonym of Deretrema Linton, I9Io, but this synonymy was questioned by Manter (I947) who considered it a synonym of Steganoderma Stafford, I904. Odhner (I9IIa) does not discuss the relationship of Proctophantastes with either of the genera with which it has been synonymized. Whilst Price (I934) makes his synonymy with little comment, Manter (I947) discusses the relationship of the three genera in some detail. As has been mentioned above, the latter author considers Proctophantastes to be a synonym of Steganoderma and he suggests that the differences between the typespecies of Steganoderma, S. formosum Stafford, I904, and P. abyssorum are of specific rather than generic value. These differences are in sucker-size, oesophagus-length and length of vitelline fields. The present author agrees with Manter's conclusion. Therefore, the differences Manter (I947) indicates between Steganoderma and Deretrema also apply to Proctophantastes when compared with Deretrema. In short, Price's synonymy is rejected, because the vitellaria in Deretrema do not reach posteriorly to the ventral sucker, whilst in Steganoderma and Proctophantastes the majority of the vitellaria are situated in this region. Subsequent to Manter (I947), only Yamaguti (I953, I958, I970, I97I) has continued to consider Proctophantastes a valid genus. The features he uses to distinguish Proctophantastes from Steganoderma are, I believe, not sufficient to uphold the genus. In I953 he indicates that in Proctophantastes the vitellaria are compact, while in Steganoderma they are in longitudinally elongate groups. This type of difference would appear to be of specific rather than generic importance, as it concerns fairly small details of the vitelline extent. Yamaguti (I958) distinguishes the genera on the shape of the cirrus-sac and the position of the ventral sucker. An examination of Miller's (I94I) redescription of Stafford's specimen of S. formosum, and also of the other descriptions of this species given by Manter (I925, I926), Linton (I940), Ching (I960), Ronald (I960) and Strelkov (I960) shows that the cirrus-sac of this species resembles that of $P$. abyssorum in shape. The ventral sucker in this latter species lies just behind the middle of the body, while in $S$. formosum it lies just anterior to the centre of the body. This condition probably varies with the contraction or growth of the specimen, so that its value as a generic character is rather doubtful. In I970, Yamaguti suggested that a "profusely developed "periatrial gland" may be a generic, not a specific character, though not mentioned by Odhner'. He is referring to a character present in a new species he is describing, and this character is, I believe, a feature of $\mathrm{Neo-}$ steganoderma, and is discussed in connection with the following species. The few scattered gland-cells around the genital atrium in the present specimen do not, it appears, represent a feature of generic importance, and, moreover, similar glands have been described in other species of Steganoderma, e.g. S. elongatum Manter, I947. 
Finally, Yamaguti (I97I) upholds Proctophantastes on account of the characteristic structure of the genital atrium. There is, however, no peculiar feature in the genital atrium of the present specimens, nor is it indicated in Odhner's generic definition where he merely says 'Genitalsinus ziemlich klein'. As the various attempts to validate Proctophantastes do not appear convincing, this genus is here considered to be a synonym of Steganoderma.

The present specimens show no outstanding morphological differences from $P$. abyssorum, as described by Odhner (IgIra), and are therefore considered to belong to this species. There are, however, two minor differences, the first being the sparse gland-cells around the genital atrium and the second the presence of a ridge running transversely across the inner surface of the ventral sucker. This latter feature was not easy to detect in many whole mounts and may easily have been overlooked by Odhner.

\section{Neosteganoderma glandulosum Byrd, I964, emend}

(Fig. 8)

Proctophantastes glandulosa: Yamaguti, I971.

Host and locality: intestine of Beryx decadactylus, Stn. 37.

All the worms are contracted to a broadly pyriform shape, which tapers towards the anterior end. The length varies between $\mathrm{I} \mathrm{mm}$ and $\mathrm{I} \cdot 38 \mathrm{~mm}$ and the maximum width, which occurs at the level of the testes, between $0.76 \mathrm{~mm}$ and $0.96 \mathrm{~mm}$. Anteriorly, the cuticle bears long, narrow spines which also occur near the posterior extremity. The subterminal oral sucker is rounded, $0.27-0.38 \mathrm{~mm}$ across by $0.26-0.33 \mathrm{~mm}$ long. At about the middle of the worm, or just behind, lies the transversely elongate ventral sucker, measuring $0.69-0.77 \mathrm{~mm}$ across by $0.27-0.33$ $\mathrm{mm}$ long, reaching close to the lateral margins of the body on either side. The oral : ventral sucker width ratio is $I: 2 \cdot I-2 \cdot 8$, whilst the length of both suckers is almost the same. A small prepharynx can be seen in serial section. It enters a globular pharynx of about 0.II-0.I3 mm diameter. The oesophagus is fairly short, curved dorsally to the pharynx, and bifurcates just posteriorly to the pharynx. The caeca are quite short, reaching to a position dorsal to the testes.

The excretory pore is terminally situated, or, when the worm is greatly distended with eggs, it may appear to be slightly dorsal. The saccular vesicle reaches as far as the posterior border of the ovary, and in this region part of it lies ventrally to the seminal receptacle.

On the left side of the body, submarginally and just anterior to the ventral sucker lies the genital pore. The genital atrium has a strong muscular wall, with irregular outpocketings. Into it leads a large cirrus-sac, the bulk of which lies just anterior to the ventral sucker and at right angles to the long axis of the worm. The cirrus-sac reaches transversely across the body to the right intestinal caecum, where it twists and runs slightly posteriorly towards the centre of the ventral sucker, in a plane dorsal to the remainder of the cirrus-sac. The relatively small, coiled internal seminal 


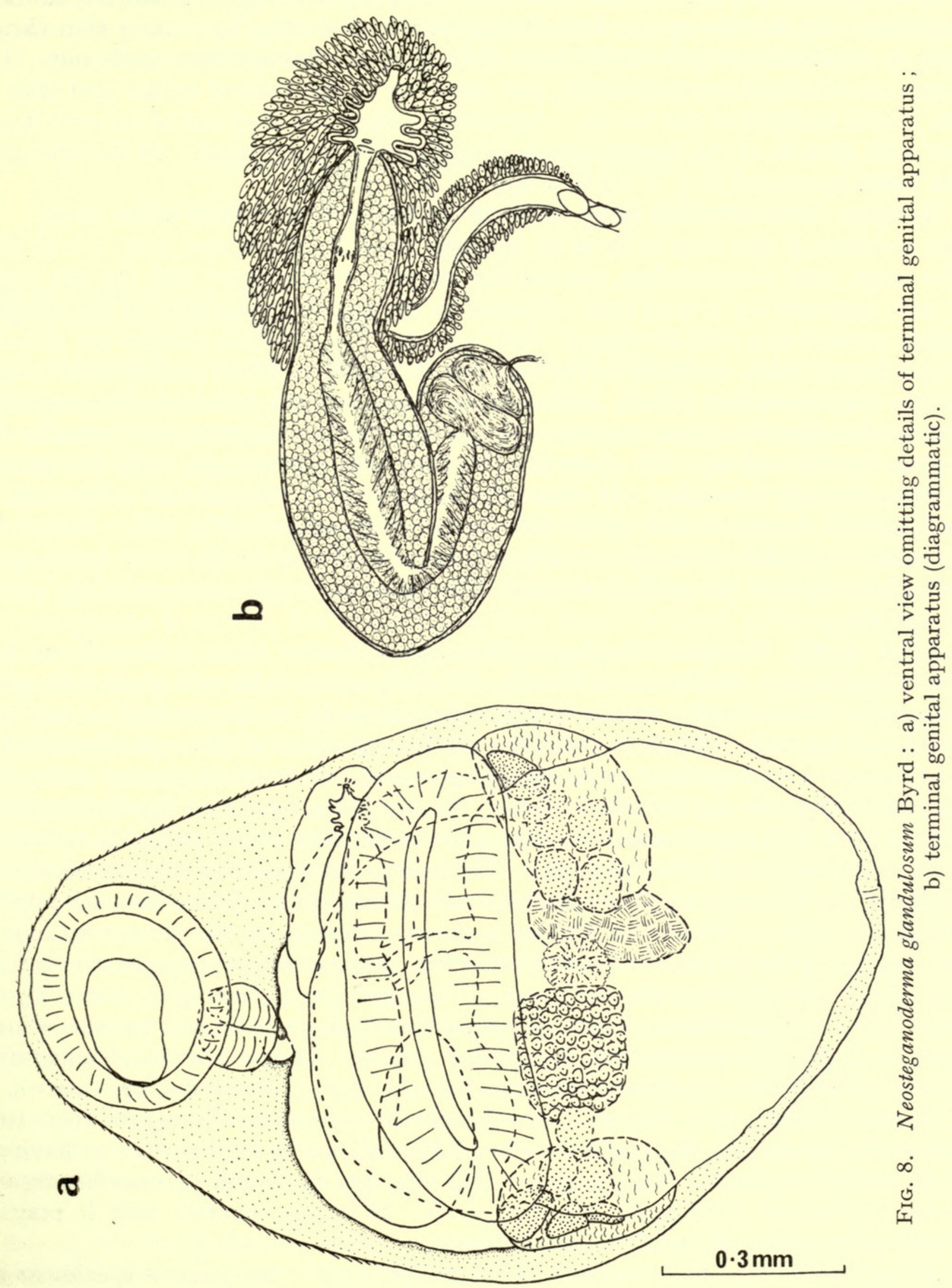


vesicle leads into a well-developed pars prostatica, which, with its innumerable associated glands, fills most of the cirrus-sac. The muscular cirrus is shorter, containing some long, narrow spines, lying lengthwise, but as they have been seen clearly only in serial section the overall shape of these spines has not been made out. The testes are arranged symmetrically, just posterior to the ventral sucker and close to the lateral margins of the worm. Apparently, normally they are of an oval shape, but with growth of the uterus certain lobe-like processes appear. In one specimen the testes measured $0.27 \times 0.3 \mathrm{~mm}$ and $0.4 \times 0.19 \mathrm{~mm}$.

Between the testes, and lying towards the right of the worm, is the ovary. In one specimen it was seen to be of an irregular quadrilateral shape, $0.27 \times 0.27 \mathrm{~mm}$. The large, oval receptaculum seminis lies dorsally to the ovary and the left testis. It may measure $0.3 \times 0.19 \mathrm{~mm}$. Ventral to the anterior extremity of the receptaculum seminis is a well-developed 'shell'-gland. The vitelline follicles are situated in two lateral fields, ventrally to the testes and reaching to about the posterior margin of the ventral sucker. Each field contains four to eight follicles. The egg-filled uterus occupies the great majority of the hindbody, obscuring the reproductive organs in this region. The metraterm is long and, particularly near the genital atrium, strongly muscular. It enters the latter from the dorsal side. For most of its length it is surrounded by an investment of gland-cells (Fig. 8b). Where the metraterm and the cirrus-sac run adjacent to each other the cells invest both organs and also surround the genital atrium. The operculate eggs measure $26-3 \mathrm{I} \mu \mathrm{m} \times$ I6-2I $\mu \mathrm{m}$.

Byrd (I964) described Neosteganoderma glandulosum from a beryciform fish, Polymixia lowei, in the Straits of Florida. He differentiated his new genus from other zoogonids with follicular vitellaria situated posteriorly to the ventral sucker by a number of features. These included the posterior position of the ventral sucker and the elongate oesophagus and forebody, but as can be seen from the present contracted specimens these are not reliable features. It should be noted that Byrd's specimens were treated with chloretone in sea-water before fixation, which probably accounted for the relaxation of the forebody. The other distinguishing characteristics he mentions are the very large ventral sucker and the "large glandular mass surrounding the genital pore'. The latter feature is very prominent in the present specimens and appears to be the most reliable feature for distinguishing Neosteganoderma from the closely-related genus Steganoderma. Yamaguti (I97I), however, places Byrd's species in Proctophantastes, which, as pointed out above, does not possess a large mass of gland-cells surrounding the genital atrium. It appears that Yamaguti is basing his definition of Proctophantastes Odhner, I9II, not on its type-species, $P$. abyssorum Odhner, I9II, but on his own species $P$. polymixiae Yamaguti, I970, from Polymixia japonica in the Pacific Ocean off Hawaii, which he describes as having a large 'periatrial gland'. This suggests that this species should become Neosteganoderma polymixiae (Yamaguti, I970) n. comb. It seems possible that it may be found to be conspecific with $N$. glandulosum.

As stated above, certain features of the morphology of the present specimens are different from those described by Byrd, but these are considered to be due to the differences in the fixation technique used. The oesophagus in the present forms is 
particularly reduced by comparison with the original description. Byrd's statement that the metraterm enters the genital atrium from the ventral side appears to be a typographical error, as a close examination of his figures shows that in his specimens, as in mine, the metraterm enters the genital atrium from the dorsal side.

\section{Family FELLODISTOMIDAE Nicoll, I9I3}

\section{(?) Steringotrema divergens (Rud, I809) Odhner, I9II}

(Fig. 9)

Distoma divergens Rud., 1809.

Fasciola divergens : de Blainville, 1820.

Host and locality: intestine of Capros aper, Stn. 38, Stn. 53.

Seven specimens were recovered from a fish at Stn. 38 and two from a fish at Stn. 53. These specimens are, unfortunately, rather contracted, but enough detail has been observed to suggest that they probably belong to Steringotrema divergens.

The worms are oval, often tapering at each end, and measure $0 \cdot 75^{-\mathrm{I}} \cdot 2 \mathrm{~mm}$ long by $0.42-0.47 \mathrm{~mm}$ in maximum width at the level of the ventral sucker. The cuticle is unarmed. The subterminal oral sucker is $0.1 \mathrm{I}-0.15 \mathrm{~mm}$ in diameter and leads into a globular pharynx of 0.09-0.II mm diameter. Because of the contraction the oesophagus is curved, but it bifurcates just about the level of the genital pore, and the intestinal caeca extend to about the level of the testes. About halfway along the body lies the transversely-elongate ventral sucker, measuring $0 \cdot 2 \mathrm{I}-$ $0.3 \mathrm{I} \mathrm{mm} \times 0.38-0.42 \mathrm{~mm}$, giving an oral : ventral sucker ratio of about $\mathrm{I}: 2 \cdot 7-3 \cdot 6$.

The excretory pore is terminal, and the vesicle is V-shaped, the limbs of which have been traced almost to the ventral sucker in serial sections.

About halfway between the suckers and just to the left of the median line lies the genital pore. The rather stout cirrus-sac, 0.I8-0.I9 mm long and $0.1 \mathrm{I}-0.13 \mathrm{~mm}$ wide, contains a bipartite seminal vesicle leading into an elongate pars prostatica which passes from the anterior end of the seminal vesicle to near the posterior end of the cirrus-sac before turning and running anteriorly to unite with a short, muscular, smooth cirrus. Due to contraction of the body, the testes, the ovary and the eggfilled uterus are pressed closely against the ventral sucker. Thus, as the eggs are opaque, the testes and the ovary are discernible only in serial section. The testes lie symmetrically at the lateral margins of the body, with the ovary lying close to the right testis. The vitelline follicles are arranged in four groups, two on each side of the worm, one group anterior to the ventral sucker and the other group posterior to the sucker. The uterus fills almost the whole of the hindbody of the worm and contains numerous operculate eggs, $46-48 \mu \mathrm{m} \times 33-37 \mu \mathrm{m}$ with shell about $2-3 \mu \mathrm{m}$ thick.

Any slight morphological differences which can be detected between the above description and those given by Odhner (I9IIb), Palombi (I93I) and Mathias (I934) may probably be explained by the contraction of the present worms. The eggs, as measured when teased from the body as well as in utero, are rather wider than those 


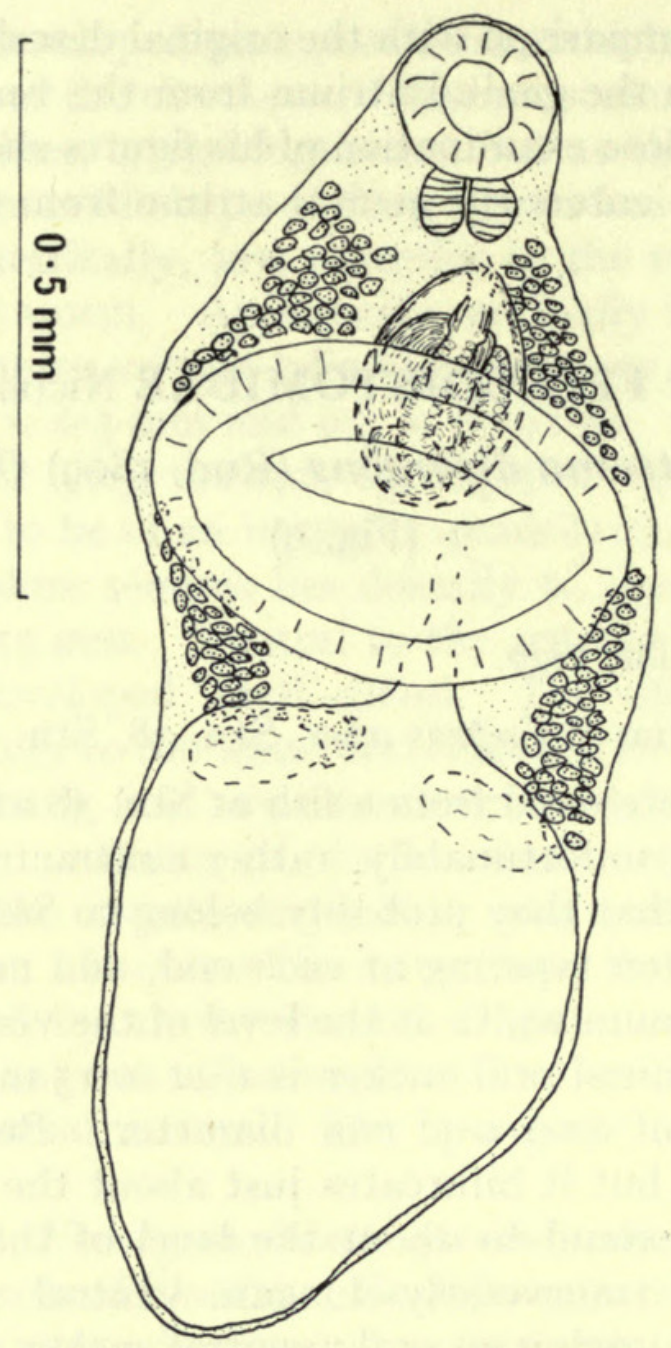

FIG. 9. (?) Steringotrema divergens (Rud.) : diagrammatic ventral view with intestine omitted.

previously recorded. A more definite statement on the identity of these specimens awaits better-preserved material. It should be noticed that the previously-reported hosts of $S$. divergens (i.e. gobies and blennies) have a rather different biology from that of the present host.

Steringophorus blackeri sp. nov.

(Fig. Io)

Hosts and localities : intestine and body-cavity of Xenodermichthys copei (type-host),

Stn. 24 ; intestine of Xenodermichthys sp. indet., National Institute of Oceanography, Stn. $6429-28^{\circ} 07^{\prime}$ N., I3 ${ }^{\circ} 52^{\prime}$ W. depth o-390 m.

Four whole specimens were recovered from $X$. copei. One whole specimen and an anterior fragment were found in the body-cavity of the same fish specimen, the fish itself having itself been preserved in formalin. The remainder of the specimens from $X$. copei and the two specimens found in $X$. sp. indet. were taken from the intestine. The worms occurred either singly or in pairs in their hosts. The whole worm from the body-cavity (Fig. Iob) was of a shape and size rather different from 

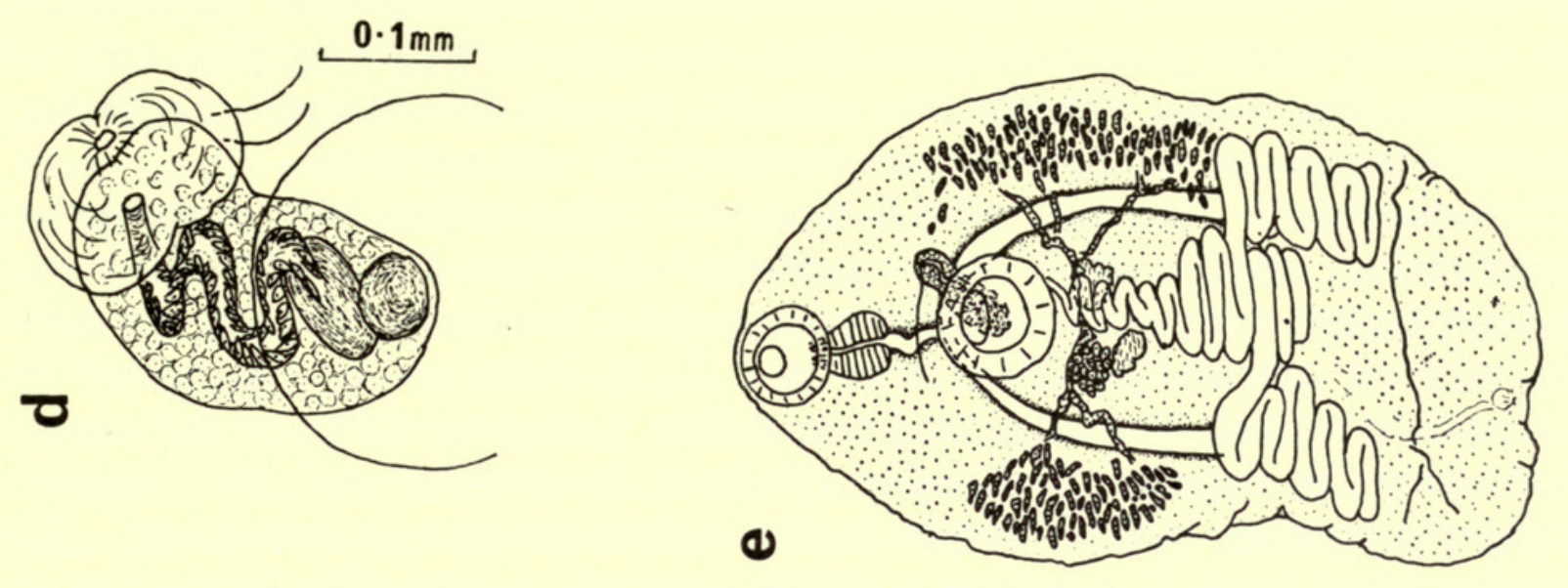

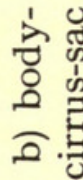

วิำ



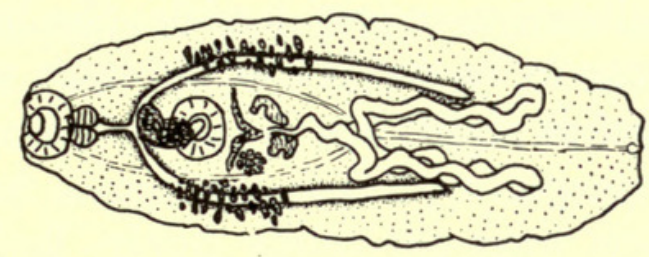

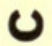
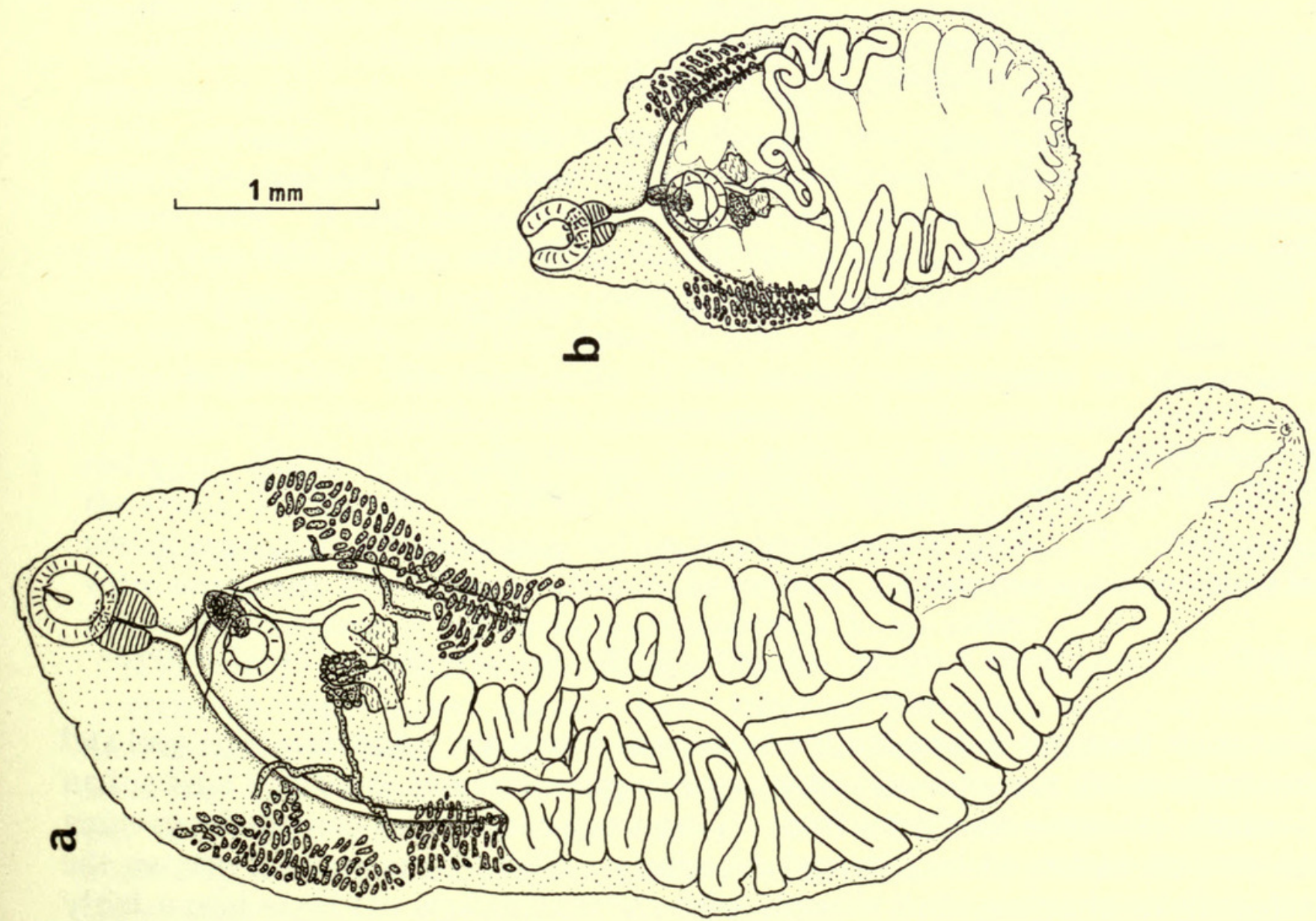

ह

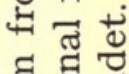

घี ज्ञ

क्ष

สี.

$\exists$ ox

总

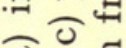

..

․․ㅇ

施

듀

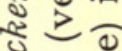

तू

उ०

ठิำ

क्ष

พั

定点

ن 
those in the intestine (Fig. Ioa), two of which were sectioned for further study. The other specimens, collected by the author from fishes in the collection of the National Institute of Oceanography, included one which was apparently young (Fig. Ioc) and an older worm (Fig. Ioe). Despite the variation in size, the internal morphology indicates clearly that all these specimens represent the same species.

The 'intestinal form' from $X$. copei is elongate, being widest just posteriorly to the ventral sucker, which is about one-fifth of the body-length from the anterior end. The forebody tapers sharply, while the tapering of the hindbody is less pronounced, and it is rounded terminally. The forms from $X$. sp. indet are much smaller, but with a similarly shaped forebody, and are widest just posteriorly to the ventral sucker (at about one-third of the body-length from the anterior end), the hindbody having slightly tapering lateral margins and a rather truncate posterior end. The 'body-cavity form' from $X$. copei has a similar forebody to the other forms, but the hindbody is considerably swollen by the large bulbous excretory vesicle, the limbs of which reach into the forebody, but do not appear to be swollen in the same way.

The dimensions of the various forms are included in Table 2.

\section{TABLE 2}

Measurements of Steringophorus blackeri sp. nov.

\begin{tabular}{|c|c|c|c|c|}
\hline Host & $X$. copei & $X$. copei & $X$. sp. indet. & $X$. sp. indet. \\
\hline 'Form' & Intestinal & Body-cavity & Younger & Older \\
\hline No. of specimens & 3 (2 sectioned) & $I+$ fragment & I & I \\
\hline Length (mm) & $4^{\cdot 6-9}$ & $2 \cdot 7$ & $2 \cdot 2$ & $3 \cdot 08$ \\
\hline Width (mm) & $2 \cdot 03-2 \cdot 04$ & $I \cdot 45$ & $0 \cdot 8$ & $\mathrm{I} \cdot 68$ \\
\hline $\begin{array}{l}\text { Oral sucker } \\
\quad \text { diameter }(\mathrm{mm})\end{array}$ & 0.47 & $0.34-0.35$ & 0.243 & 0.4 \\
\hline $\begin{array}{l}\text { Ventral sucker } \\
\text { diameter }(\mathrm{mm})\end{array}$ & 0.43 & $0.29-0.33$ & $0 \cdot 240$ & 0.45 \\
\hline $\begin{array}{l}\text { Oral : ventral } \\
\text { sucker ratio }\end{array}$ & I : 0.92 & I $: 0.85-0.94$ & I : 0.98 & I : I·I2 \\
\hline Pharynx (mm) & $0.32 \times 0.26$ & $\begin{array}{r}0.22-0.26 \times \\
0.21-0.19\end{array}$ & $0.125 \times 0.11$ & $0.21 \times 0.25$ \\
\hline Oesophagus (mm) & $0.13-0.23$ & $\mathrm{O} \cdot \mathrm{I}_{4}$ & O.IO5 & $0 \cdot 16$ \\
\hline Cirrus-sac (mm) & $\begin{array}{l}\text { about } 0.32-0.35 \\
\quad \times 0.19\end{array}$ & $\begin{array}{l}\text { about } 0.21-0.32 \\
\times 0.12\end{array}$ & $0.26 \times 0.14$ & $0.48 \times 0.16$ \\
\hline Ovary (mm) & 0.27 dia. & $0.21 \times 0.16$ & $0.18 \times 0.1 I$ & $0.21 \times 0.19$ \\
\hline Testes (mm) & $\begin{array}{l}\text { about } 0.21 \times \\
0.18\end{array}$ & $\begin{array}{l}0.11-0.12 \times \\
0.16\end{array}$ & $\begin{array}{l}0.07-0.13 \times \\
0.14\end{array}$ & $\begin{array}{c}0.13-0.14 \times \\
0.17-0.2\end{array}$ \\
\hline Eggs $(\mu \mathrm{m})$ & $57-63 \times 32-34$ & $5^{2-5} 8 \times 27-30$ & $54 \times 27-30$ & $54-57 \times 28-3 c$ \\
\hline
\end{tabular}

The cuticle bears no spines, but has numerous transverse wrinkles. The oral and ventral suckers are rounded, and with one exception the oral is slightly larger than the ventral. In some specimens from $X$. copei contraction has caused the opening of the ventral sucker to be disposed anteriorly. There is no prepharynx, so the almost globular pharynx abuts directly with the oral sucker. It leads into a fairly short oesophagus, which bifurcates at about the level of the anterior margin of the ventral sucker, or slightly further forward. The intestinal caeca are lined with a 
glandular epithelium and run posteriorly to a point normally amidst the uterine coils where they terminate, about halfway along the hindbody.

The excretory pore is terminal and leads into a very small globular vesicle (of about $0.03-0.06 \mathrm{~mm}$ in diameter) before entering the main $Y$-shaped vesicle. The stem of the vesicle reaches to about the middle of the body, whilst the limbs reach anteriorly to the oral sucker. The stem may be very wide or narrow, but the limbs are constantly narrow. The excretory pore itself appears to be on a short protuberance at the base of a depression and is surrounded by glandular cells.

The genital pore is situated on a level with, or just anterior to, the intestinal bifurcation and slightly to the left of the median line. It leads into a muscular genital atrium. The cirrus-sac overlaps the anterior border of the ventral sucker and contains a relatively small, bipartite seminal vesicle, a long, coiled pars prostatica and a short muscular cirrus. The testes lie posteriorly to the ventral sucker a little obliquely to each other, with the left testis being slightly anterior to the right. They are close to the ovary and to each other, are small by comparison with the body-size and have more or less deeply indented margins. The multilobate ovary lies anteriorly and sometimes slightly obliquely to the right testis. It is associated with a large 'shell'-gland, about the same size as the ovary, lying between it and the left testis. Laurer's canal opens dorsally, level with the 'shell'-gland, and may contain a small amount of spermatozoa in its proximal region. Sperm may also lie in the proximal part of the uterus. The vitellaria consists of numerous globular or short transversely-elongate follicles disposed in two symmetrically placed fields near the lateral margins of the body. These fields reach from about the level of the anterior border of the ventral sucker to a position some distance posterior to the testes. The uterus runs in the median line from the ovary to about the middle of the worm, in a series of lateral coils. It then forms a descending series of loops on each side of the body to about two-thirds of the way along the hindbody before passing anteriorly again as a series of loops. It has not been possible to ascertain whether the uterus passes down one side of the body and then down the other, or whether it divides before passing down both sides. The later coils of the uterus pass forward in the median line ventrally to the descending coils and the gonads. In the specimens with the swollen excretory vesicle the lateral uterine slings are forced to lie close to the margins of the body. Within the uterus lie numerous eggs, many of which are collapsed, but which appear to be operculate, with a brownish-yellow shell. This shell is covered with numerous small bosses giving the surface a granular appearance, which is rather less marked in the young specimen from $X$. sp. indet.

Material. British Museum (Natural History) Reg. no. I973.4.9.2I-24 (syntypes).

Although some recent authors have followed Yamaguti (I953) in considering Steringophorus Odhner, I905, a synonym of Fellodistomum Stafford, I904, it would seem that there may be one feature differentiating these genera, if the distribution of the vitellaria is taken into consideration. In Fellodistomum the vitellaria extend anteriorly well beyond the ventral sucker, whilst in Steringophorus they do not. A close examination of material of the type-species of both genera from the type-hosts may well indicate other differences, particularly in the length of the caeca and the configuration of the fully-developed uterus. 
This new species would appear to be most closely related to Steringophorus magnus Manter, I934, from an unidentified eel-like fish in 300 fathoms at Tortugas, Florida. It differs, however, in the granular pattern of the egg-shell, in the sucker ratio, in the distribution of the vitellaria and in the configuration of the uterus in the hindbody. The sculpturing on the egg-shell seems to be similar to that described in Benthotrema plenum Manter, I934, and it may be noted that although Manter (I934) originally considered this to be a generic character, later (I954) he described a further species in the genus, $B$. richardsoni, in which the eggs apparently have smooth shells.

\section{Family HEMIURIDAE Lühe, I9oI}

\section{Hemiurus appendiculatus (Rud., I802) Looss, I899}

Host and locality: stomach of Alosa fallax, Stn. 4I.

Seven specimens were found. This is a common parasite of shads and has been recorded in $A$. fallax $[A$. finta] in various localities in the Mediterranean and northeastern Atlantic. Nevertheless, H. appendiculatus of de Oliveira Rodrigues et al. (I972) recorded from $A$. fallax from the coast of Portugal may not belong to this species, as it has, judging from the authors' figure, a relatively short pars prostatica and an undivided seminal vesicle. The normal condition appears to be that represented by the present specimens, in which the pars prostatica is convoluted posteriorly to the ventral sucker, and in which the anterior part of the bipartite seminal vesicle has a thick muscular wall.

\section{Lecithocladium excisum (Rud., I8I9) Lühe, I90I}

Host and locality : stomach of Scomber scombrus, Stn. 44.

\section{Lecithochirium gravidum Looss, 1907}

Host and locality: stomach of Conger conger, Stn. 7 .

In their revision of Lecithochirium Lühe, I90I, Nasir and Diaz (I97I) consider $L$. gravidum to be a synonym of $L$. rufoviride (Rud., I8I9). These two species are certainly very similar morphologically and according to Looss (I908) and Guiart (I938) they are distinguishable only by size and sucker ratio. L. gravidum is small with an oral : ventral sucker ratio of about $\mathrm{I}: 2$ whilst rufoviride is larger and has suckers of more or less equal size. The present specimens (six in number) have an oral sucker diameter of $0 \cdot 24-0.29 \mathrm{~mm}$ and a ventral sucker diameter of $0.47-0.52 \mathrm{~mm}$, and therefore a sucker ratio of $\mathrm{I}: \mathrm{I} \cdot 8-2 \cdot \mathrm{I}$. In an attempt to discover whether or not the sucker ratio in this group is influenced by allometric growth 60 specimens, assigned to one or other of these species, were measured. These specimens, from the collections of the British Museum (Natural History), were all from Conger conger collected at Plymouth and Guernsey. The sucker ratio was then plotted against the body-length as is shown in Fig. II. As can be seen there are two distinct regions, one representing those specimens with a sucker ratio of more than $I: I \cdot 7$ and the other representing those with a ratio of less than $I: I \cdot 6$. Allometric growth does 


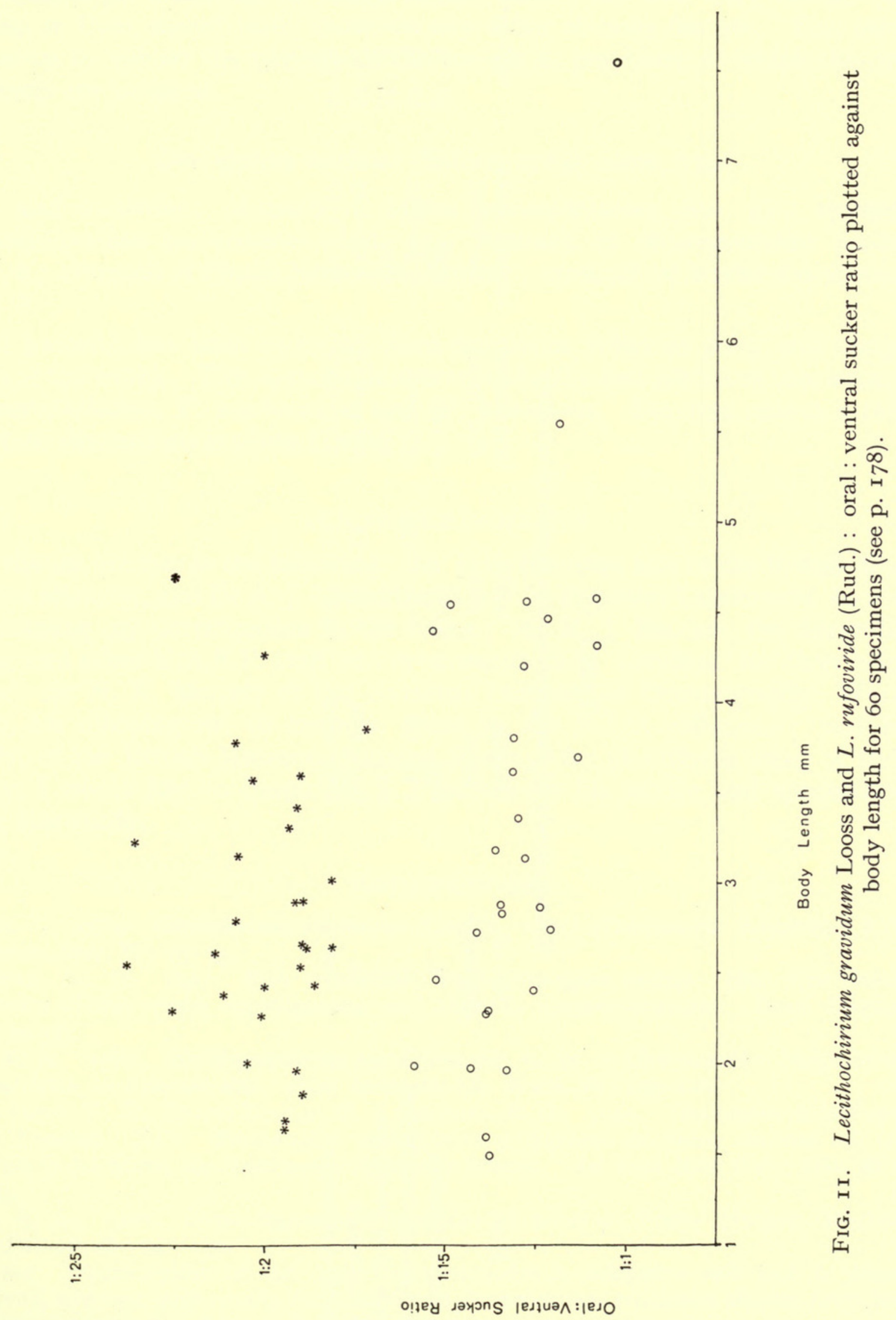




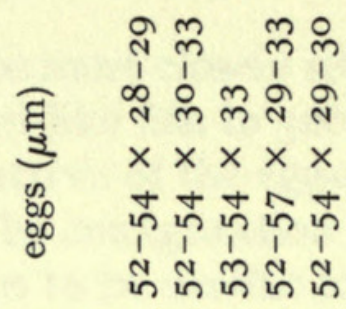

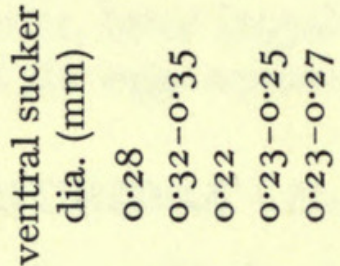

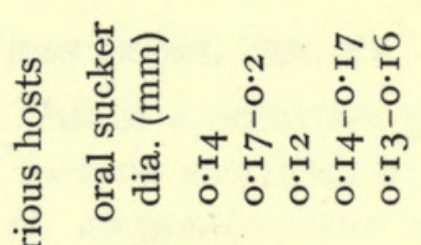

$>$

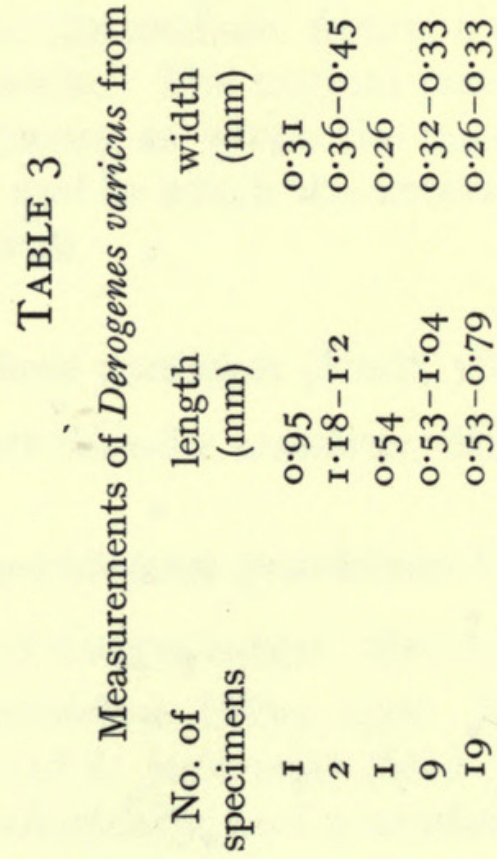

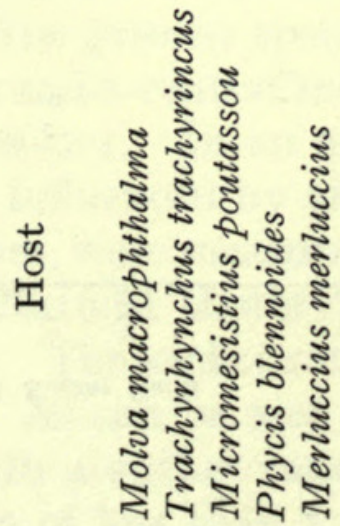


not appear to have a significant effect on the sucker ratio. It can therefore be seen that, commonly occurring in Conger conger, there are two very similar species differing in their sucker ratio, if not in any other obvious feature. This information seems to uphold the validity of the species L. gravidum, to which the present specimens are assigned.

\section{Derogenes varicus (Müller, I784) Looss, I90I}

Hosts and localities: stomach of Molva macrophthalma, Stn. 43; stomach of Trachyrhynchus trachyrincus, Stn. 43; stomach of Micromesistius poutassou, Stn. 6 ; stomach of Phycis blennoides, Stn. I7 ; stomach of Merluccius merluccius, Stn. 8 .

This parasite has been recorded from numerous fishes in polar and temperate waters of the world. This appears, however, to be the first record of this worm from $M$. macrophthalma, T. trachyrincus and $M$. poutassou. For this reason a table of important dimensions is given (Table 3).

\section{ACKNOWLEDGMENTS}

My thanks are due to the following: Dr J. P. Harding, late of the British Museum (Natural History), and Dr A. J. Lee of the M.A.F.F. Fisheries Laboratory, Lowestoft, for arranging my participation in the cruise; Mr R. J. Blacker, the naturalist-incharge, and other M.A.F.F. staff and crew members of 'Cirolana' for their help and advice; Dr N. R. Merrett of the National Institute of Oceanography, Wormley, Surrey, for allowing me to examine fishes in the N.I.O. collection; and $\mathrm{Mr} \mathrm{A}$. Wheeler of the British Museum (Natural History) for identifying some of the fish. Finally, I would like to thank Mr S. Prudhoe for his advice and encouragement during this study.

\section{REFERENCES}

BRÅten, T. I964. Otodistomum veliporum (Creplin, I837) (Trematoda, Azygiidae) i Norge. Fauna, Oslo, 17 : 73-75.

Brinkman, A., Jr. I957. Fish trematodes from Norwegian waters. IIa. The Norwegian species of the orders Aspidogastrea and Digenea (Gasterostomata). Univ. Bergen Avb. 4:29 pp.

Byrd, M. A. I964. Neosteganoderma glandulosa gen. n., sp. n. (Trematoda: Steganodermatidae) from an Atlantic fish. Proc. helminth. Soc. Wash. 31 : 105-Io8.

Caballero y. C., E., Bravo Hollis, M. \& Grocott, R. G. I955. Helmintos de la Republica de Panama. XIV. Trematodos monogeneos y digeneos de peces marinos del Oceano Pacifico del Norte, con descripcion de neuvas formas. An. Inst. Biol. Univ. Mex. 26 : I I7I47.

Ching, H. L. I960. Some digenetic trematodes of fishes of Friday Harbor, Washington. J. Parasit. $46: 24 \mathrm{I}-250$.

- 1961. Redescription of the digenetic trematodes Lepidapedon calli and L. pugetensis Acena, and new host records for L. calli and Eurycreadium vitellosum Manter from fishes of Washington State. Can. J. Zool. 39:6I5-62I.

Crowcroft, P. W. I95I. Notes on the taxonomy of the genus Coitocaecum Nicoll, I9I5 (Digenea : Opecoelidae). J. Parasit. $37: 25 \mathrm{I}-256$. 
Dawes, B. I947. The Trematoda of British fishes. Ray Society, London : 364 pp.

de Oliveira Rodrigues, H., Carvalho Varela, M., Sodré Rodrigues, S. \& Cristofaro, R. 1972. Alguns trematódeos digeneticos de peixes do Oceano Atlântico. - Costa Continental Portuguêsa e Costa Continental da África. Atas Soc. Biol. Rio de J. 15 : 87-93.

Dogiel, V. I936. [Parasites of cod from Lake Mogilnoe.] Uchen. Zap. leningr. gos. Univ. 3 (7) : 123-I33. (In Russian.)

Dollfus, R. P. I937. Les trématodes Digenea des sélaciens (Plagiostomes). Catalogue par hôtes. Distribution géographique. Annls Parasit. hum. comp. 15 : 57-73.

Guiart, J. I938. Trématodes parasites provenant des campagnes scientifiques du Prince Albert $\mathrm{I}^{\mathrm{er}}$ de Monaco (1886-I9I2). Result. Camp. scient. Prince Albert 99: $84 \mathrm{pp}$.

Gupta, N. K. \& Sehgal, S. K. I97I. Some allocreadiid trematodes from marine food fishes of India. Res. Bull. Panjab Univ. Sci. 21 : 267-275.

Hanson, M. L. I950. Some digenetic trematodes of marine fishes of Bermuda. Proc. helminth. Soc. Wash. $17:$ 74-89.

Kabata, Z. I96I. A new genus and species of trematode parasitic in Macrurus fabricii (Sundeval), a deep-sea fish. Proc. Zool. Soc. Lond. 136 : 285-292.

Lebour, M. V. 1908. Fish trematodes of the Northumberland coast. Rep. Invest. Northumb. Sea Fish. Comm. (1907) : II-57.

Linton, E. I940. Trematodes from fishes mainly from the Woods Hole region, Mass. Proc. U.S. natn. Mus. 88 : I-I72.

Looss, A. I908. Beiträge zur Systematik der Distomen. Zur Kenntnis der Familie Hemiuridae. Zool. Jb. (Syst.) 26:63-I8o.

Machida, M., Ichihara, A. \& Kamegai, S. I970. Digenetic trematodes collected from fishes in the sea north of Tsushima Islands. Mem. natn. Sci. Mus., Tokyo 3 : IoI-II2.

Maillard, C. I970. Nicolla elongata n. sp. (Digenea, Coitocaecidae) parasite d'Onos tricirratus (Brunnich, I768) (Teleostei). Bull. Mus. natn. Hist. nat. Paris 42 : 4I0-4I4.

Manter, H. W. I925. Some marine fish trematodes of Maine. J. Parasit. 12 : II-I8.

— I926. Some North American fish trematodes. Illinois biol. Monogr. 10 : I27-264. - 1934. Some digenetic trematodes from deep-sea fish of Tortugas, Florida. Papers Tortugas Lab., Carnegie Inst. Washington 28 : 257-345.

- 1947. The digenetic trematodes of marine fishes of Tortugas, Florida. Am. Midl. Nat. 38 : 257-4I6.

I954. Some digenetic trematodes from fishes of New Zealand. Trans. R. Soc. N.Z. $82: 475-568$.

Mathias, P. I934. Sur quelques Trématodes de poissons marins de la région de Banyuls. Archs Zool. exp. gen. 75: 567-581.

Matthews, R. A. I973. The life-cycle of Prosorhynchus crucibulum (Rudolphi, I8I9) Odhner, I905, and a comparison of its cercaria with that of Prosorhynchus squamatus Odhner, I905. Pavasitology 66 : $\mathrm{I} 33-\mathrm{I} 64$.

Miller, M. J. I94I. A critical study of Stafford's report on 'Trematodes of Canadian fishes' based on his trematode collection. Can. J. Res. 19:28-52.

NASIR, P. \& DiAz, M. T. I97I. A revision of genus Lecithochirium Luehe, I90I, and redescription of L. monticellii (Linton, I898) Skrjabin and Guschanskaja, I955. Riv. Parassit. $32: 27-36$.

Nicoll, W. I9I5. The trematode parasites of north Queensland. III. Parasites of fishes. Parasitology $8: 22-4 \mathrm{I}$.

Odhner, T. Igira. Zum natürlichen System der digenen Trematoden. II. Zool. Anz. $37: 237-253$.

- I9ı Ib. Zum natürlichen System der digenen Trematoden. III. (Ein weiterer Fall von sekundärem Anus.) Zool. Anz. 38 : 97-II 7.

OzAKI, Y. I928. Some gasterostomatous trematodes of Japan. Jap. J. Zool. 2:35-6o.

Palombi, A. I93I. Per una migliore conoscenza dei Trematodi endoparassiti dei pesci del golfo di Napoli. I. - Steringotrema divergens (Rud.) e Haploporus benedeni (Stoss.). Annuar. Mus. zool. Univ. Napoli 6 : I-I5. 
Polyansky, Y. I. I955. Parasites of the fish of the Barents Sea. Trudy zool. Inst. Leningr. 19:5-I70. (English translation: Israel program for scientific translations, Jerusalem, 1966.)

Price, E. W. I934. New digenetic trematodes from marine fishes. Smithson. misc. Collns $91(7): \mathrm{I}-8$.

Pritchard, M. H. I966. Studies on digenetic trematodes of Hawaiian fishes. Family Opecoelidae Ozaki, 1925. Zool. Jb. (Syst.) 93 : I73-202.

Ronald, K. I960. The metazoan parasites of the Heterosomata of the Gulf of St. Lawrence. VI. Digenea. Can. J. Zool. $38: 923-937$.

Skrjabin, K. I. \& Koval, V. P. I96o. Suborder Allocreadiata Skrjabin, Petrov and Koval, 1958. Part two. In: Skrjabin, K. I., Ed. Trematodes of animals and man. Principles of trematodology. Moscow, 18: I5-377. (English translation: Israel program for scientific translations, Jerusalem I965.)

Slusarski, W. I97I. A redescription of Nicolla testiobliqua (L. W. Wisniewski, I933) R. Ph. Dollfus, 1958, a fish trematode from Bosnia and some remarks on the present status of European and other representatives of the family Coitocaecidae Ozaki, I928 (Podocotyloidea R. Ph. Dollfus, I960). Acta parasit. Pol. 19: I2I-I32.

Strelkov, J. A. I960. Endoparasitic worms of marine fishes of East Kamchatka. Trudy zool. Inst. Leningr. 28 : I47-196.

Tendeiro, J. I955. Sobre um novo trematódeo digenético, Dolichoenterum manteri n. sp., parasita do safio, Conger conger (L.) algumas considerações sobre a sistematica da subordem Gasterostomata Odhner, 1905. Bolm Soc. port. Ciênc. nat. 20 : 19-43.

Williams, H. H. I96o. A list of parasitic worms, including 22 new records, from marine fishes caught off the British Isles. Ann. Mag. nat. Hist. Ser. 13 2: 705-715.

Yamaguti, S. I934. Studies on the helminth fauna of Japan. Part 2. Trematodes of fishes. I. Jap. J. Zool. 5:249-54I.

- I938. Studies on the helminth fauna of Japan. Part 2I. Trematodes of fishes. IV. Kyoto, Japan : I39 pp.

1953. Systema Helminthum. Part I. Digenetic trematodes of fishes. Tokyo, Japan: 405 pp.

I958. Systema Helminthum. I. The digenetic trematodes of vertebrates. Interscience Publishers Inc., New York: I575 pp.

1970. The digenetic trematodes of Hawaiian fishes. Keigaku Publishing Co., Tokyo: $436 \mathrm{pp}$.

I971. Synopsis of digenetic trematodes of vertebrates. Keigaku Publishing Co., Tokyo: I074 pp.

R. A. BRAY

Department of Zoology

British Museum (Natural History)

Cromwell RoAd

LoNDON SW7 7 BD 


\section{$2 \mathrm{BHL}$ Biodiversity Heritage Library}

Bray, Rodney Alan. 1973. "Some digenetic trematodes in fishes from the Bay of Biscay and nearby waters." Bulletin of the British Museum (Natural History) Zoology 26, 151-183. https://doi.org/10.5962/bhl.part.205.

View This Item Online: https://www.biodiversitylibrary.org/item/19502

DOI: https://doi.org/10.5962/bhl.part.205

Permalink: https://www.biodiversitylibrary.org/partpdf/205

\section{Holding Institution}

Natural History Museum Library, London

\section{Sponsored by}

Natural History Museum Library, London

\section{Copyright \& Reuse}

Copyright Status: In copyright. Digitized with the permission of the rights holder.

Rights Holder: The Trustees of the Natural History Museum, London

License: http://creativecommons.org/licenses/by-nc-sa/4.0/

Rights: http://biodiversitylibrary.org/permissions

This document was created from content at the Biodiversity Heritage Library, the world's largest open access digital library for biodiversity literature and archives. Visit BHL at https://www.biodiversitylibrary.org. 